Article

\title{
A Grounded Theory on Sustainable Circular Public Procurement in Germany: Specific Product Case and Strategies
}

\author{
Simone Wurster ${ }^{1, *}$, Rita Schulze ${ }^{2}$, Ramona G. Simon ${ }^{2}$ and Stefan Hoyer ${ }^{3}$ \\ 1 Department of Innovation Economics, Technische Universität Berlin (TU Berlin), 10587 Berlin, Germany \\ 2 DECHEMA e.V., Theodor-Heuss-Allee 25, 60486 Frankfurt am Main, Germany; \\ rita.schulze@dechema.de (R.S.); ramona.simon@dechema.de (R.G.S.) \\ 3 Department of Lightweight Structures and Polymer Technology, Technische Universität Chemnitz, \\ 09107 Chemnitz, Germany; stefan.hoyer@mb.tu-chemnitz.de \\ * Correspondence: simone.wurster@tu-berlin.de
}

check for updates

Citation: Wurster, S.; Schulze, R.; Simon, R.G.; Hoyer, S. A Grounded Theory on Sustainable Circular Public Procurement in Germany: Specific Product Case and Strategies. Sustainability 2021, 13, 13525. https:/ / doi.org/10.3390/su132413525

Academic Editor: Luigi Aldieri

Received: 30 September 2021 Accepted: 23 November 2021 Published: 7 December 2021

Publisher's Note: MDPI stays neutral with regard to jurisdictional claims in published maps and institutional affiliations.

Copyright: (c) 2021 by the authors. Licensee MDPI, Basel, Switzerland. This article is an open access article distributed under the terms and conditions of the Creative Commons Attribution (CC BY) license (https:/ / creativecommons.org/licenses/by/ $4.0 /)$.

\begin{abstract}
By using its purchasing power to procure environmentally friendly goods and services, the public sector can significantly contribute to sustainability in production and consumption. The sector's support is also needed for the development of a circular economy (CE), but the absence of a suitable procurement practice often constitutes a barrier. A pressing example for a global need to develop the CE further exists in the tyre context. By the end of 2030, the number of end-of-life tyres (ELT) is expected to rise significantly. This article analyses the role and situation of public procurement and the necessity of quality infrastructure elements to support a sustainable tyre CE in the European Union's member state Germany. It relies on a multiple case case study-based Grounded Theory approach and 22 interviews with public procurement professionals. Five types of barriers for sustainable circular tyre procurement were identified, concerning regulatory, technical, social, market, and ecological aspects. Possible strategies to overcome them were developed, leading to 14 recommendations for German policymakers and public procurement organisations. In particular, the recommendations focus on the two quality infrastructure elements 'standards' and 'labelling', with four standardization aspects and eight labelling topics in total.
\end{abstract}

Keywords: circular economy; public procurement; sustainability; tyres; policy instruments; quality infrastructure; Grounded Theory

\section{Introduction}

\subsection{Motivation for This Research}

This article provides insight into an under-represented public procurement topic. It is dedicated to potential policy instruments and strategies to promote a sustainable circular economy (CE) for tyres, highlighting, e.g., quality infrastructure needs regarding tendering criteria and labels, information platforms, and awareness campaigns.

On a global scale, approximately five million end-of-life tyres (ELT) arise worldwide on a daily basis [1,2] and until 2030, the number of discarded tyres is expected to rise exponentially [3]. The product-independent CE concept addresses this problem. The CE concept does not only envisage a decrease in landfilling of discarded products [4], but also in incineration. In addition, it is regenerative and restorative, works with renewable energies, and intends to maintain resources in the highest possible quality condition. At the same time, it offers special economic growth opportunities (see [5,6]). The most commonly used definition of CE is provided by Kirchherr et al. (2017) [6]:

"A circular economy 'describes an economic system that is based on business models which replace the 'end-of-life' concept with reducing, alternatively reusing, recycling, and recovering materials in production/distribution and consumption processes [...], with the aim to accomplish sustainable development, which implies creating environmental 
quality, economic prosperity and social equity, to the benefit of current and future generations". ([6], p. 224)

According to [7], Table 1, the tyre management options that can support the objectives of a CE concept include: 1 . "Refuse via reducing vehicle ownership and using alternative modes of transport"; 2 . "Reduce via life extension", 3. "Resell/Reuse discarded tyres which are safe and functional"; 4 . "Remanufacture by retreading functionally sound discarded tyres"; 5. "Repurpose without or using less physical or chemical treatment;" 6. "Recycling via processes including devulcanization and grinding" and 7. "Recovery of raw materials via pyrolysis or of energy via incineration".

Table 1. Key circular economy rules and regulations on tyres from a German perspective.

\begin{tabular}{|c|c|}
\hline Tyre Life Cycle Stage/Tyre Management Options & Relevant Rules \\
\hline Design and production & $\begin{array}{l}\text { Directive 2008/98/EC (Waste Framework Directive), its update } \\
\text { by Regulation (EU) 2018/581 and the KrWG to consider the } \\
\text { waste hierarchy already in the design phase } \\
\text { Regulation (EC) No. } 1907 / 2006 \text { (REACH), Regulation (EU) No. } \\
1272 / 2013 \text {, and Regulation (EU) 2018/1513 } \\
\text { Regulation (EC) No. 661/2009, from } 2022 \text { Regulation (EU) } \\
2019 / 2144 \text { (type approval of motor vehicles and components) } \\
\text { Depending on the application, Regulation No. } 30 \text { or } 54 \text { of the } \\
\text { UN/ECE for passenger cars and trucks for type approval }\end{array}$ \\
\hline Distribution & $\begin{array}{l}\text { Regulation (EC) No. } 661 / 2009 \text {, from } 2022 \text { Regulation (EU) } \\
2019 / 2144 \text { (type approval of motor vehicles and components) } \\
\text { Regulation (EC) No. 1222/2009 (tyre labeling in general) }\end{array}$ \\
\hline Consumption & $\begin{array}{l}\text { Regulation (EU) } 2019 / 2144 \text { mentioned above } \\
\text { General rules of the Climate Protection Act and the KrWG (e.g. } \\
\text { part } 5, \S 45 \text { ) on public procurement }\end{array}$ \\
\hline Collection & $\begin{array}{l}\text { Basel Agreement as a general framework } \\
\text { Requirements for national take-back systems } \\
\text { KrWG, AltfahrzeugV, AbfAEV, NachwV, EfbV }\end{array}$ \\
\hline Reduction and Induction & $\begin{array}{l}\text { KrWG, Directive 1999/31/EC on landfills, DepV } \\
\text { Directive 2000/53/EC on end-of-life vehicles, AltfahrzeugV } \\
\text { Regulation (EC) No. 1907/2006, Regulation (EU) 1272/2013 } \\
\text { Musterverwaltungsvorschrift technische Baubestimmungen } \\
\text { and corresponding state building laws, } \\
\text { General rules of the KrWG on public procurement }\end{array}$ \\
\hline Modification & $\begin{array}{l}\text { Directive } 89 / 459 / \text { EEC } \\
\text { UN/ECE } 108 \text { and 109, The Council (2006) regarding the } \\
\text { adoption in the EU }\end{array}$ \\
\hline
\end{tabular}

Note: In addition, the law of several Federal States requires the consideration of social aspects in public procurement according to ILO core working standards or at least the purchase of products from suppliers who ensure production without child labor. Special rules are also included in the SächsKrWBodSchG law of the Federal State Saxony. More specific requirements on ELT management are specified in the guide "Leitfaden umweltverträgliche Beschaffung der freien Hansestadt Hamburg" of the Federal State Hamburg.

In addition to environmental aspects of the circular economy, this article is also about ensuring that tyres meet at least basic social sustainability requirements with fair working conditions along the life cycle in accordance with ILO Core Labour Standards (see, e.g., [8-10] for details). Tyres whose production, use and ELT management contribute to the CE principles according to options 4 or 6 of [7] ("Remanufacture by retreading functionally sound discarded tyres" and "Recycling via processes in-cluding devulcanization and grinding") and meet at least these international working standards are referred to as "sustainable CE tyres" in this article. 
This article addresses the CE aim of preserving resources at the highest possible quality. Specific emphasis is put on options 4 and 6 of [7], i.e., retreaded tyres and recycling. Particular consideration is also given to the replacement market for tyres. As shown in detail in the next sections, the paper provides answers to three questions regarding public tyre procurement in the EU Member State Germany:

(1) Which procedures are mainly applied to procure tyres and which selection criteria are mainly adopted in the procurement processes?

(2) Which barriers exist to take greater account of the United Nations Sustainable Development Goals (UN SDGs) and the German Circular Economy Act (Kreislaufwirtschaftsgesetz, KrWG) in the procurement of vehicular tyres?

(3) In response to the barriers mentioned in question 2, which strategies could support the procurement of sustainable $\mathrm{CE}$ tyres?

To answer these questions, a Grounded Theory (GT) approach based on a multiple-case case study was chosen to understand barriers and possible strategies to stimulate circular public tyre procurement in Germany. This article is structured as follows: Sections 1.2-1.5 provide information on the key elements of this study, public procurement and tyres as well as relevant framework conditions for a tyre CE. Section 2 presents the study materials and methods. Then, Section 3 provides information on the cases, procurement patterns, barriers to procuring sustainable CE tyres, and, finally, solutions to address the obstacles on the basis of the interviews. The article concludes with a discussion in Section 4 and a conclusion and outlook in Section 5.

\subsection{State of the Art in Circular Public Procurement Research}

The public sector is a major demand-side market player, accounting for about $13 \%$ of worldwide GDP, about USD 11 trillion in 2018 [11]. Germany's public procurement alone has a volume of around EUR 500 billion. Moreover, the public sector is not only a dominant buyer. It also strongly influences demand-side innovations [12,13]. Specifically, ref. [12] describes 'the importance of demand-side approaches to innovation and, more concretely, in the use of public demand as an engine for innovation' at European Union level.

Using the public sector's purchasing power to procure environmentally friendly goods and services can significantly contribute to sustainability in production and consumption. It can also help create a critical mass to demand more sustainable goods and services that would otherwise be difficult to bring to market. At the same time, the public sector is seen as a role model in procurement [13]. However, the absence of suitable procurement practices can be a barrier to the development of certain markets. In this context, [14] identified missing circular procurement as a barrier to the CE.

The United Nations' '2030 Agenda for Sustainable Development' describes clear sustainability goals for public procurement in their UN SDG 12.7-'Promote public procurement practices that are sustainable, in line with national policies and priorities.' Furthermore, efforts to make public procurement more environmentally friendly and at the same time more innovative are visible at the level of the European Union (EU). In this context, the European Commission defines circular public procurement (CPP) as:

'the process by which public authorities purchase works, goods or services that seek to contribute to closed energy and material loops within supply chains, while minimising, and in the best case avoiding, negative environmental impacts and waste creation across their whole life-cycle' [15] (p. 5) 
The literature was reviewed in order to get an overview of research on the role of public procurement and its CE-related activities. An analysis in the Web of Knowledge database for the search term 'circular economy,' refined with 'public procurement,' led to 32 hits. Two publications were not available. An additional 14 contributions were not considered for review because on closer inspection, the topics did not fit into the scope of this review. One article focussed on business models, one on consumption, two on ecolabels in general, and three contributors dealt with green public procurement (GPP) in general. Three other articles deemed unsuitable for this review were focussing on management aspects, a platform, and product life cycle extensions, while three further articles were about supply chains or value chains. One author team mentioned the CE only in the outlook.

The remaining 16 contributions were selected for the review. Amongst those were three articles that present public procurement as part of instrument mixes (a) in the EU [16] and (b) in public organisations [17,18]. Specifically, ref. [16] investigated expectations from the EU on necessary policies for transitioning towards a CE. In addition to expanding circular procurement, the following were considered promising solutions: (a) more advanced standards in production, (b) tax reliefs for circular products, (c) deregulation in the area of waste trading and support for trading on digital platforms, (d) support for eco-industrial parks, and (e) awareness campaigns. Two articles on the impact of GPP in general also showed its specific influence on the CE and its development $[19,20]$.

To specify the framework conditions for successful CPP, ref. [21] analysed the state of the art of GPP and sustainable public procurement (SPP) in three areas: organisational aspects, individual behaviour and practices, and operational tools. In addition, refs. [21,22] also highlight the importance of Ecolabels for the CE.

Alhola et al. [23] provide CPP selection criteria of different sectors, also including the mobility sector, where their focus was on fuels for cars and buses. Five other papers focus on individual sectors: two articles on the construction sector [24,25], one on medicine [26], one on catering [27], and one on information and communication technologies [28]. The remaining three papers address the relationship between the CE and other SPP approaches [28,29], priority policy areas [28], and benefits of collaborations between public procurement and suppliers [30]. Various other subjects have not yet been analysed in-depth in previous research. Furthermore, some policy options are not applicable in individual contexts or too vague. Sönnichsen and Clement [21], for example provided a useful overview on GPP and SPP but announced that details on CPP were still pending. Moreover, the multitude of remaining policy options raises the question as to which option is particularly suitable in the present context to move closer to the CE objectives by taking $\mathrm{CE}$ into account in public procurement. The European Commission [15] differentiates between system-level procurement (including, e.g., public-private partnerships), supplierlevel procurement, and product-level CPP. Supplier level CPP includes, e.g., supplier take-back systems, design for disassembly practices, reparability of standard products, external reuse or sale of products and internal reuse of products. Characteristics of the product models are, e.g., that materials in the product can be identified, products can be disassembled after use, contain recyclable and recycled materials and, finally, resource efficiency.

\subsection{Prerequisites of Tyres Regarding the Circular Economy}

Tyres are products characterised by a high degree of complexity. Their main component, rubber, cannot be easily recycled for the production of new tyres due to the almost irreversible cross-linking. In addition, there are a large number of manufacturer- and component-specific rubber compounds. Tyres are made up of a large number of individual components, each of which tends to have a different material composition (rubber compound). It is therefore difficult to impossible to recover single-variety tyre recyclates. This severely limits their recyclability into caoutchouc-based materials in general, which is why the quantities mixed into new tyres today are minimal. The use of ELT recyclates in 
new rubber compounds can lead to undesirable property losses or chemical interactions (cross-linking disorders or accelerated ageing), which is why the substitution of virgin materials is not trivial. The proportion of substituted secondary raw materials from ELT recycling for the production of new tyres is currently limited to approx. $5 \%$ in a single tyre component or approx. $2-3 \%$ in relation to the total tyre. Another obstacle to establishing the production of tyres with a high ELT content is the concern about safety losses compared to tyres made predominantly from virgin materials. Tyre safety is of paramount importance. The utilisation of ELT recyclates carries the risk of unpredictable disturbances of the sensitive cross-linking reaction (vulcanisation) in the tyre manufacturing process. Reasons for this are, for example, contamination of the ELT or the unnoticed introduction of so-called rubber poisons such as copper or manganese compounds. The consequence can be an increased failure rate of tyres, especially due to critical abrupt failure. The use of recycled rubber is also usually associated with a deterioration in service value properties (e.g., rolling resistance, abrasion, fatigue), which may compromise the overall environmental benefit from using the recyclates. The underlying development work is accordingly complex and time-consuming.

Therefore, ELT recyclates are nowadays mainly processed into secondary products, usually embedded in other, less complex (i.e., not rubber-based) matrix materials, such as polyurethane. One example is the production of mats as fall protection or for the absorption of sound and vibration. Here, chemical interactions do not play such a predominant role, so that the exact material composition of the recyclates is less decisive [31].

The tyres' content of polycyclic aromatic hydrocarbons (PAHs) can pose a barrier to using the recyclates for purposes other than tyres. PAHs result from the incomplete combustion of organic matter and naturally occur in coal and petroleum. Tyres often contain relevant amounts of PAHs, mainly due to the filler carbon black. Numerous PAHs have been proven to be carcinogenic. However, there is disagreement in the scientific community about the extent to which the mere PAH content allows statements about health effects. For tyres, PAH limits apply to the plasticizer content only, but not to the PAH contained in the carbon black. On the other hand, in many areas of consumer products, the total PAH content of the materials is regulated. Products that regularly come into contact with the hand or mouth or are used in recreational areas (e.g., playground surfaces, handles, or cushioning pads), may therefore sometimes only contain a certain percentage of ELT recyclates.

Leading manufacturers are working intensively on a wide range of sustainable circular tyre solutions. Examples include the BlackCycle project with Michelin's participation, Michelin's innovative pyrolysis process and their work on using recycled PET in tyre cord, and Goodyear's research into the use of rice waste in tyre production. They also include Continental's 'Conti-Life-Cycle' tyre retreading plant, see [32]. Although retreaded tyres are occasionally used in cars, more support is needed to develop a tyre CE and to stimulate the willingness to use new sustainable tyre variants (see, e.g., [33] regarding traditional acceptance problems of retreaded tyres).

\subsection{Public Procurement Practice in Germany}

Germany's public procurement takes place nationally, on the level of the Federal States (named 'Länder'), and in municipalities. Box 1 provides details. The country's public procurement is influenced by both European and national regulation. Box 2 provides an overview of important framework conditions. 
Box 1. Public procurement structures in Germany.

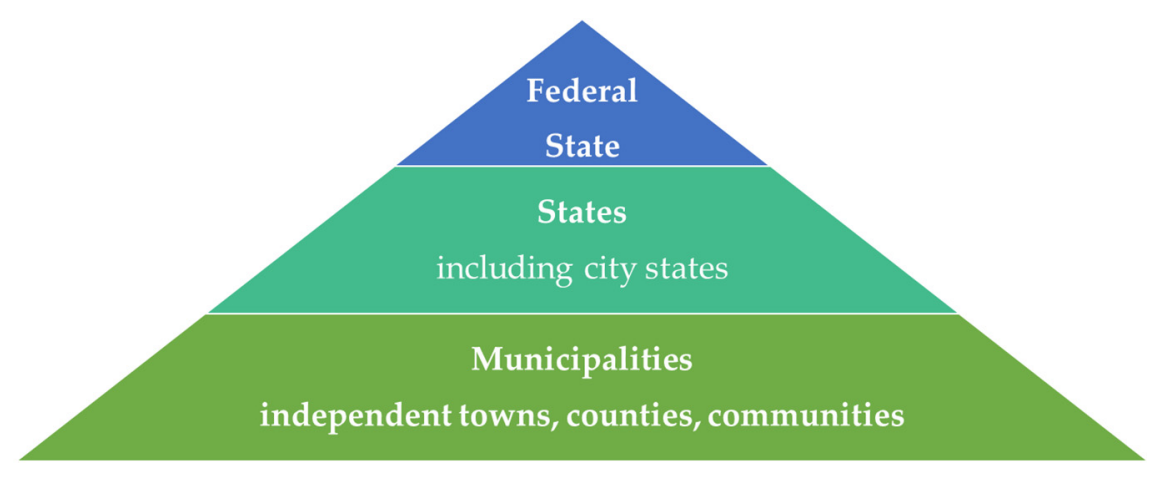

Germany's public procurement takes place on the federal and national level. Procurement in the individual Federal States is organized individually and differently by each state. There are central procurement offices, such as in the state of Rhineland-Palatinate, but there are also states in which public procurement is decentralized. The state administration of North Rhine-Westphalia offers an example of decentralized purchasing processes. In this state administration, purchasing is carried out by the individual departments (Ressorts). The degree of centralization within the departments varies. In rare cases, products are procured jointly by several authorities of this Federal State. Most commonly, in the two example states, the procurement units act individually. This article's interview series considers this variety. (Source: own figure inspired by [34]).

Box 2. Fundamental public procurement rules in Germany.

General procedure of public procurement in Germany

Germany's legal framework for public procurement is based on the European Directives 2014/23 EU, 2014/24/EU [35], which is particularly relevant in the given context and Directive 2014/25/EU. In 2016, Germany transposed the directives into German law. This resulted in an update of the Act against Restraints of Competition (Gesetz gegen Wettbewerbsbeschränkung, GWB), in the publication of the Procurement Ordinance (Vergabeverordnung, VgV), and of two other regulations. Procedural rules are specified in the Subthreshold Procurement Ordinance (Unterschwellenvergabeordnung, UVgO), and in the Procurement and Contract Regulations for Construction Works Parts A and B (Vergabe- und Vertragsordnungen für Bauleistungen Teil A und $\mathrm{B}, \mathrm{VOB} / \mathrm{A}$ and VOB/B) $[36,37]$. The Federal States have further rules for public procurement.

Relevant procurement procedures according to the UVgO are (see [38,39]):

$\S 9$ Public invitation to tender

$\S 10$ Restricted invitation to tender with competition (up to an anticipated contract value of EUR 100,000)

$\S 11$ Restricted invitation to tender without competition

$\S 12$ Negotiated award with or without a call for competition (up to EUR 10,000 without competive bidding)

$\S 14$ Direct contract (up to an anticipated contract value of EUR 1000).

Box 2 refers to fundamental European and national framework conditions. When the EU directives were transposed into German law, the environmental aspects were also anchored.

In 2015, the European Commission adopted the first EU CE Action Plan and in 2019 the Commission adopted the final Circular Economy Package. Germany's Kreislaufwirtschaftsgesetz KrWG was published in 2012 and updated several times after 2019. The Federal Climate Change Act (September 2019) [40] and the Section 45 of the KrWG have also added the requirement to take account of climate protection and regulations to focus on purchasing resource-saving products. 
Internationally, the UN SDG No. 12 includes the target 12.7 (also called SDG 12.7) "Promote sustainable public procurement practices in accordance with national policies and priorities." In the European context, the new EU CE Action Plan (March 2020) also takes into account developments towards more environmentally friendly public procurement [41]. However, the public procurers have different possibilities to (voluntarily) consider environmentally friendly aspects during purchasing. For example, it can be reflected whether a new product is required or if a used or rented product is more favourable. Another consideration can be made about reusability, repairability, and recyclability. Additionally, labels that indicate sustainability aspects can be used as guidance to purchase environmentally friendly products [36]. It is possible to receive support from the Federal Environment Agency [42], the Sustainable Procurement Competence Centre [43] and from the Kompass Nachhaltigkeit (Sustainability Compass) [44].

\subsection{Tyre Policies and Gaps}

An overview of possible instruments to promote sustainable production and consumption in general is provided by [45]. The authors of [45] identify, for example, regulatory instruments that limit manufacturers' options through statutory limits and taxes, but also incentives for more sustainable production and utilization of products. Various measures also already exist with regard to the life cycle of tyres. They were analysed by the authors and their project partners, including experts from three core areas of the tyre life cycle: raw material production, tyre manufacturing, and ELT management. Table 1 provides an overview of the key documents identified. Further details can be found at [46].

Most of these documents deal with (a) the supply side of tyres and (b) the end of life of tyres, see for example, the line in the table on the design and production phase. The consumption phase is less underpinned by specifications, and there are only general rules. Incentives to produce or use sustainable CE tyres could hardly be identified by this article's authors.

In addition to specific tyre-related regulations, there are also new frameworks and regulations that focus on the demand side of tyres. An important element in this context is the UN SDGs. They contain, for example, requirements for public procurement, in particular specified by the above mentioned UN SDG 12.7 .

Relevant regulations in the EU and Germany are, for example, the EU CE Action Plan, the new CE Action Plan and the German Circular Economy Act (KrWG) mentioned in Section 1.4. However, Germany lacks specific guidelines and concepts for the circular public procurement of tyres (CPP). Therefore, this article will analyse how this SDG and the KrWG are currently addressed in relation to tyre procurement in Germany and what a suitable way forward could look like. As many instruments are regulations, possible incentives to promote tyre CPP will also be analysed. According to the classification of [15], circular procurement of tyres is a mix of CPP at supplier and product level. As shown in Section 1.2, sector- and process-level analyses in public procurement and circular economy are still limited. With regard to the global waste tyre problem, this gap is of particular importance.

\section{Materials and Methods}

\subsection{Qualitative Research}

The explorative research questions presented above require detailed insights into the processes required to successfully implement circular tyre procurement in Germany. The value of quantitative research methods is limited in this context. Qualitative research, referring to socio-economic approaches, offers ways to obtain the desired insights. The results of qualitative research do not primarily arise from statistical procedures or other types of quantification, but data collected with a variety of different procedures, cf. [47]. In this article, a combination of Grounded Theory (GT) and case study research is used. 


\subsection{Principles of the Grounded Theory Approach}

The objective of GT-based research is to develop a theory that can explain and, with limitations, predict social processes [48,49]. The term 'Grounded Theory' refers to a method and a research style for discovering theories grounded in data [48]. Strauss and Corbin [47] describe a 'grounded' theory as an object-anchored theory that is inductively derived from the investigation of a phenomenon under consideration. A GT is discovered, elaborated, and tentatively confirmed through systematic collection and analysis of data related to the phenomenon under study. At the time of its creation, the theory to be formed is already empirically proved by the interdependence of empiricism and theory, cf. [49,50]. Theoretical sampling is to be carried out until theoretical saturation is reached. The more comprehensive the theoretical sampling, the more conditions, and variations are discovered and incorporated into the theory, the greater its generalisability, precision, and predictive power. If further variations are discovered later, these can be inserted as improvements to the original theory, cf. [47].

\subsection{Case Study Research}

This research's phenomenon will be explored by using the GT methodology in combination with case study research. A case study is 'a research strategy which focuses on understanding the dynamics present within single settings' [51], p. 534. Case studies are considered particularly suitable when 'how' or 'why' questions related to a research topic need to be answered, cf. [52]. Two variants, single-case and multiple-case studies are distinguished. Each case selection should either aim to confirm previous results or allow different results for predictive purposes, cf. [51,52]. When applying the GT methodology, theoretical sampling represents another significant research element, cf. [47]. For the process of data collection, the use of multiple sources of evidence and securing the chain of evidence are of particular importance, cf. [51].

\subsection{Development of the Working Model}

In order to address the research questions, the paradigmatic GT model of [47] was specified. According to Figure 1, the causal condition refers to the initial procurement situation. The transition process to circular public tyre procurement embodies the phenomenon based on European and German law such as the German KrWG, whose context is shaped by the type of tyres the procurers are looking for and the market offer. Reaction strategies including the involvement of various stakeholders are required to reach sustainable CPP as a consequence.

\subsection{Interview Concept}

The problem-centred interview, according to [53] is closely linked with the GT. It was chosen as a means for the collection of the data required to answer the research questions. An interview guide was prepared to discuss procurement processes, sustainability criteria, barriers of circular tyre procurement, and the need for support to stimulate a more circular public procurement. In addition to the topics of this study, software support for circular purchase decisions was discussed. A draft of the interview guide was created and discussed within the team of the national research project ConCirMy, funded by the German Federal Ministry of Education and Research. Based on the team's input, the guide shown in Appendix A was used for data collection. 


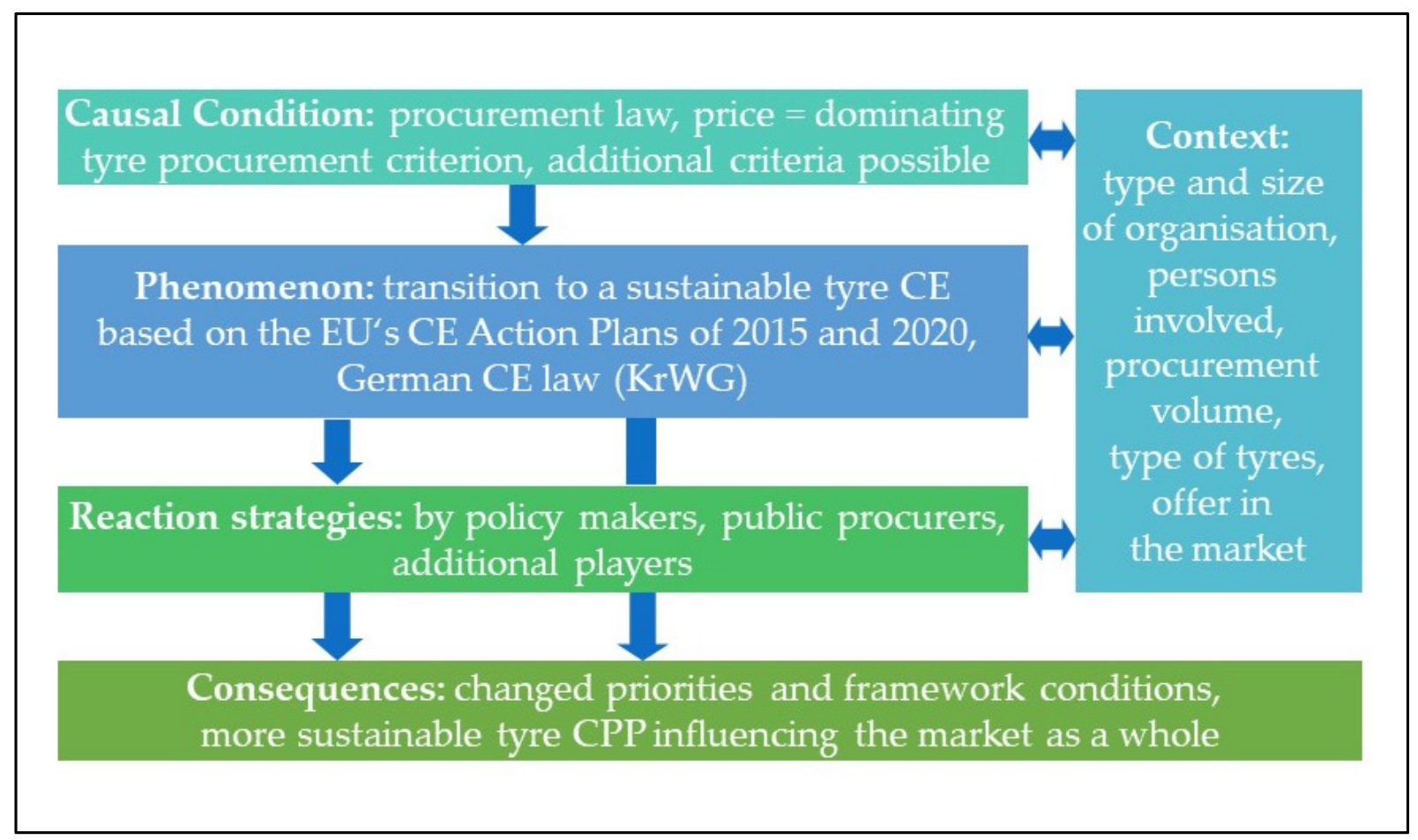

Figure 1. Initial Grounded Theory model for this study.

\subsection{Data Collection, Analysis, and Interpretation}

The data collection relied on an interview series with 22 public procurement professionals conducted between December 2020 and April 2021.

The interviewees were selected according to three criteria: (a) relevance of tyre procurement in their organization (e.g., information on car fleets), (b) significant differences in annual tyre procurement volumes, (c) variety regarding the type of organisation according to Box 1 and regions, (d) involvement of additional experts to get insight in specific details.

As a first group, professionals purchasing tyres in high quantities where chosen. For this purpose, databases of European and national calls for tenders were screened. In addition, fleet managers of Federal States, cities and districts were identified and contacted based on web research. Additional interviewees were recruited to provide insights in the context of car purchasing and leasing as well as information on additional broader framework conditions.

Table 2 and Appendix B provide details on the interviewees, their organisations, and the interviews, mainly conducted by phone. To present results, all interviews were numbered. For data protection reasons, the number is not identical with the line in Table 2. All interview candidates were selected and contacted directly. Interview requests were sent individually to all potential respondents by email. If necessary, interview candidates were contacted again by phone or an additional email about a week after the invitation. Electronic communication was used where interview partners could not be reached over the phone. The interviews had an average length of $39 \mathrm{~min}$. In one case, public procurement professionals gave their answers in writing and provided detailed information on relevant documents for public tyre procurement. 
Table 2. Overview of interviews according to their organisation's procurement level.

\begin{tabular}{|c|c|c|c|c|}
\hline Procurement Level & Federal State & $\begin{array}{l}\text { Type of Public } \\
\text { Organisation }\end{array}$ & Interview Date & Interview Length \\
\hline \multirow{2}{*}{ Federal } & - & Public procurement office & 4 March 2021 & Written answers \\
\hline & - & Federal organisation & 17 December 2020 & $60 \mathrm{~min}$ \\
\hline \multirow{4}{*}{ States } & Federal State 1 & Central procurement office & 10 February 2021 & $60 \mathrm{~min}$ \\
\hline & Federal State 2 & Central procurement office & 18 February 2021 & $27 \mathrm{~min}$ \\
\hline & Federal State 2 & $\begin{array}{l}\text { The central fleet of } \\
\text { the police }\end{array}$ & 4 March 2021 & $58 \mathrm{~min}$ \\
\hline & Federal State 3 & $\begin{array}{l}\text { Central procurement of } \\
\text { the police }\end{array}$ & 26 February 2021 & $60 \mathrm{~min}$ \\
\hline \multirow{16}{*}{ Municipalities } & Berlin & $\begin{array}{c}\text { Procurement unit of a } \\
\text { public } \\
\text { institution }\end{array}$ & 2 March 2021 & $10 \mathrm{~min}$ \\
\hline & $\begin{array}{l}\text { North Rhine- } \\
\text { Westphalia }\end{array}$ & $\begin{array}{l}\text { A municipal company for } \\
\text { street cleaning and waste } \\
\text { disposal }\end{array}$ & 10 March 2021 & $20 \mathrm{~min}$ \\
\hline & Schleswig-Holstein & $\begin{array}{l}\text { A municipal waste } \\
\text { management company }\end{array}$ & 18 February 2021 & $30 \mathrm{~min}$ \\
\hline & $\begin{array}{l}\text { North Rhine- } \\
\text { Westphalia }\end{array}$ & Public utility & 15 March 2021 & $25 \mathrm{~min}$ \\
\hline & Baden-Württemberg & $\begin{array}{l}\text { Technical service of } \\
\text { medium-sized city }\end{array}$ & 16 March 2021 & $30 \mathrm{~min}$ \\
\hline & Brandenburg & $\begin{array}{l}\text { The waste management } \\
\text { company of a municipality }\end{array}$ & 19 March 2021 & $40 \mathrm{~min}$ \\
\hline & Bavaria & $\begin{array}{l}\text { Office for waste disposal, } \\
\text { street cleaning, and vehicle } \\
\text { fleet of a Bavarian city }\end{array}$ & 23 March 2021 & $27 \mathrm{~min}$ \\
\hline & Baden-Württemberg & $\begin{array}{c}\text { Central workshop of a } \\
\text { district }\end{array}$ & 25 March 2021 & $27 \mathrm{~min}$ \\
\hline & $\begin{array}{l}\text { North Rhine- } \\
\text { Westphalia }\end{array}$ & Major city & 26 March 2021 & $60 \mathrm{~min}$ \\
\hline & Saxony & A district office & 29 March 2021 & $21 \mathrm{~min}$ \\
\hline & $\begin{array}{l}\text { North Rhine- } \\
\text { Westphalia }\end{array}$ & Procurer for municipalities & 1 April 2021 & $25 \mathrm{~min}$ \\
\hline & Baden-Württemberg & $\begin{array}{l}\text { Central fleet management } \\
\text { of a big city }\end{array}$ & 8 April 2021 & $58 \mathrm{~min}$ \\
\hline & $\begin{array}{l}\text { North Rhine- } \\
\text { Westphalia }\end{array}$ & $\begin{array}{l}\text { A city's company for waste, } \\
\text { streets, and greenery }\end{array}$ & 6 April 2021 & $30 \mathrm{~min}$ \\
\hline & $\begin{array}{l}\text { North Rhine- } \\
\text { Westphalia }\end{array}$ & A district office & 7 April 2021 & $60 \mathrm{~min}$ \\
\hline & $\begin{array}{l}\text { Rhineland- } \\
\text { Palatinate }\end{array}$ & $\begin{array}{l}\text { The waste management } \\
\text { company of a district }\end{array}$ & 13 April 2021 & $17 \mathrm{~min}$ \\
\hline & $\begin{array}{l}\text { North Rhine- } \\
\text { Westphalia }\end{array}$ & A district office & 27 April 2021 & $70 \mathrm{~min}$ \\
\hline
\end{tabular}

In parallel to conducting the interviews, a report document was prepared and continually updated. The document shows the causal conditions of tyre procurement, barriers of sustainable circular tyre procurement, and possible reaction strategies. The interviews were 
documented in hand-written protocols, in most cases supplemented by audio recordings, which were transcribed shortly after the recording.

The content was analysed, and core statements were taken over into the report document. Based on the guideline topics, additional coding and thematic structuring were carried out, and notes were inserted. The design of Section 3 shows the structure of this report document, which was used for the targeted derivation of statements. The chapter works intensively with quotations to highlight the statements of the interviewees. The quotations were translated from German. Guided by axial coding, the contributions were additionally sorted based on similarities of the procurement patterns. Six patterns were identified, which led to an additional structuring of the analyses.

\section{Results}

\subsection{Specification of the GT Framework}

A key result of the data analysis was an update of the GT model draft in Figure 1. The final version in Figure 2 presents barriers to tyre CPP as the main issue and the core of the study. Work on identifying appropriate reaction strategies aimed to provide specific insights to support tyre CPP in practice.

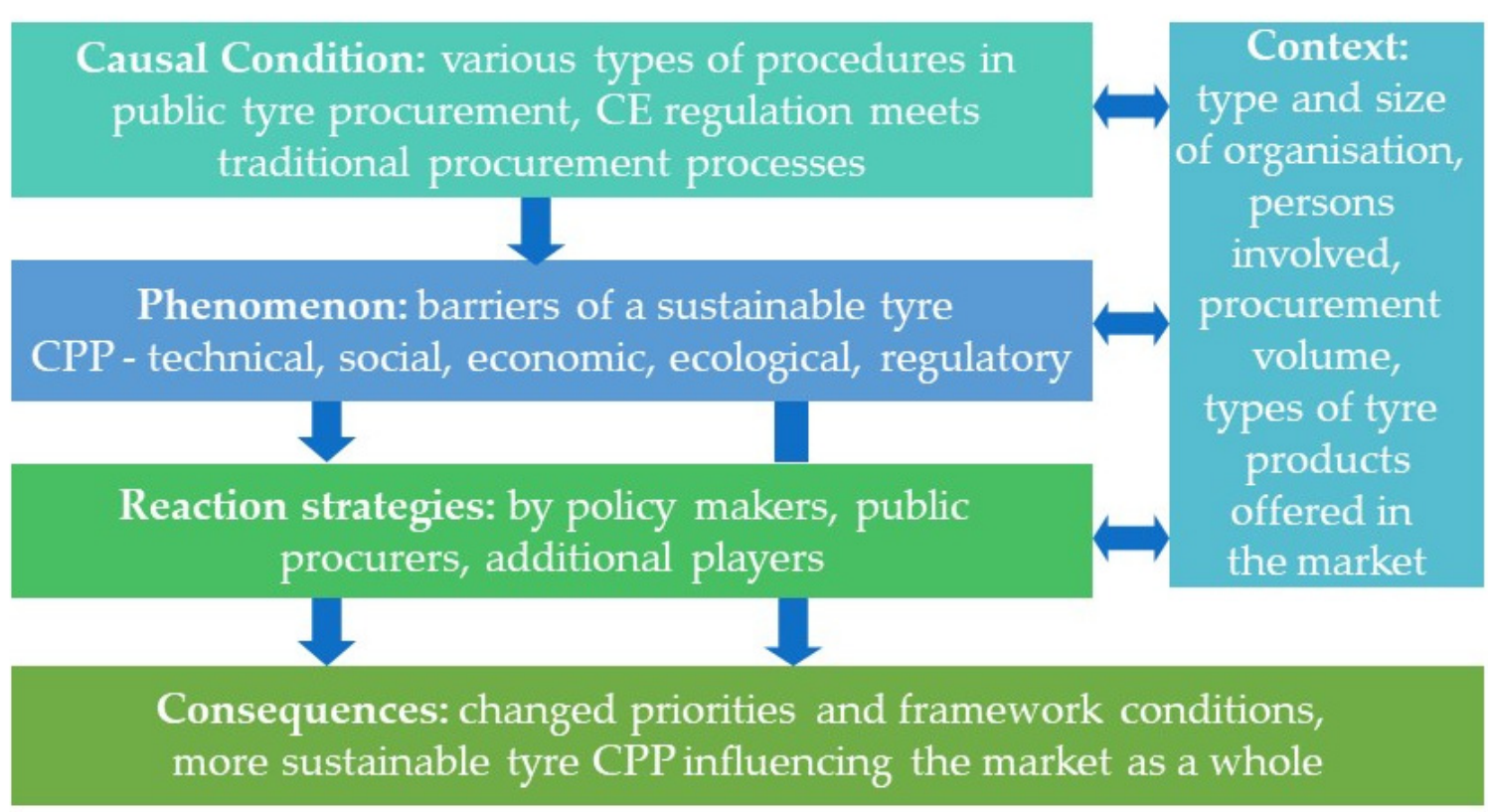

Figure 2. Modified Grounded Theory model of this study.

\subsection{Causal Condition: Current Types of Tyre Procurement}

As mentioned in Section 1.4, Germany's public procurement takes place at the level of the federal government, states, municipalities, cities, as well as through separate organisations in the cities. According to Tables 2 and 3, the interview series took this diversity into account. As a starting point, principal issues were discussed in the interview on \#1. In this context, general observations were shared, focusing mainly on public procurement by big national organizations for several ministries. 
Table 3. Summary of the procurement situations in the interviews.

\begin{tabular}{lll}
\hline Tyre Procurement Cluster & Procurement Situation & Cases * \\
\hline & $\begin{array}{l}\text { B1-Central cross-application of } \\
\text { tyre procurement and awarding } \\
\text { of supply contracts }\end{array}$ & $2,5,6,7,8,16$ \\
\cline { 2 - 3 } B-Basis types & $\begin{array}{l}\text { B2-Tyre procurement of mixed } \\
\text { volume by cities and counties }\end{array}$ & $\begin{array}{l}10,12,13,14,15,18, \\
19,20\end{array}$ \\
\cline { 2 - 3 } & $\begin{array}{l}\text { B3-Public tyre procurement by } \\
\text { public companies }\end{array}$ & $3,4,9,11,17,21$ \\
\hline & $\begin{array}{l}\text { S1-Tyre procurement for the } \\
\text { police }\end{array}$ & $5,6,7$ \\
\cline { 2 - 3 } S-Specific applications & $\begin{array}{l}\text { S2-Public tyre procurement for } \\
\text { cleaning and disposal vehicles }\end{array}$ & $3,4,11,12,17,21$ \\
\hline $\begin{array}{l}\text { T\&L-Tyre procurement as part } \\
\text { of vehicle procurement \& leasing }\end{array}$ & Leasing vehicles including tyres & 22 \\
${ }^{*}$ Case 1 included various types of clusters and was not classified specifically. & \\
\hline
\end{tabular}

Based on the interview series as a whole, six patterns of public tyre procurement could be derived: three basic types, which differ regarding the extent and complexity of the procurement processes (central cross-application of tyre procurement and awarding of supply contracts; tyre procurement of mixed volume by cities and counties, and finally, tyre procurement by public companies), tyre procurement for specific applications (for the police, cleaning and disposal vehicles) as well as tyre procurement as part of vehicle procurement and leasing. Table 3 assigns the cases to these clusters (multiple assignments possible).

Basic type B1-Central cross-application of tyre procurement and awarding of supply contracts: Centralised contracting was reported in six interviews (on cases \#2, \#5, \#6, \#7, \#8, \#16). The cases include, for example, the central procurement office of a German Federal State and the central purchase of the police in two States. Their procurement volume is several thousand tyres per year, respectively. Their organisations use EU-wide tenders for tyre procurement. One interviewee explained:

'Public procurement law distinguishes between lower and upper thresholds. The EU announces the threshold value of the contract every two years. Currently, it is EUR 214,000. If the amount is higher over the entire contract period, then I am obliged to to issue a European call for tender.'

In one case, different procurement processes are used on the EU and national levels, depending on each process's financial volume. One interviewee provided a detailed example of a procurement process:

'Tyre procurement takes place [ ... ] with several economic operators. [ ... I In the process, we work with several hundred offices or departments. All common brands and producers are included. [ ... ] On this basis, the users are given the right to choose, based on various criteria [ ... ]. A list of criteria was tendered, and bidders indicated what they could meet.'

Various criteria are used in the procurement processes. The most comprehensive overview was given by the interviewee of case \#8, see Box 3 . 
Box 3. Criteria of tyre tenders using the example of the interview on case \#8.

- $\quad$ Evaluation criteria (price, scope of delivery, EU tyre label)

- $\quad$ Compliance with EU Regulation 1222/2009

- $\quad$ Compliance with DIN standard 7803 or equivalent

- Compliance with StVZO and STVO requirements

- $\quad$ Compliance with EU tyre directive and ECE regulation no. 30 and no. 54

- $\quad$ Premium product of the respective manufacturer (= the highest quality in all areas, e.g., material selection, driving characteristics, wear properties)

- $\quad$ manufacturing plants certified according to IATF 16949

- ISO and ERTRO standards have to be fulfilled

- Compliance with the relevant standards of the German standards institute DIN and guidelines of the Trade Association of the German Rubber Industry (WDK)

Abbreviations: ECE-Economic Commission for Europe (of the United Nations), ERTROEuropean Tyre and Rim Technical Organisation, IATF-International Automotive Task Force, a working group of leading car manufacturers and their suppliers, STVO-German Road traffic regulation (Straßenverkehrsordnung), StVZO—German Road Traffic Licensing Regulations

Basic types B2 and B3-Tyre procurement of mixed volume by cities, counties, and public companies: The interviews on the city and county levels referred to tyre procurement in high and low quantities, providing particular insight into volume-related differences in the CPP processes, also compared with big EU-level tenders. In this context, the procurement of tyres in low quantities is often shaped by an awareness barrier towards SPP and CPP (see Section 3.3).

Specific application S1-Tyre procurement for the police: The interview series included three interviews on the procurement of tyres for police cars. All three interviewees procured tyres in high quantity, particularly on the EU level, involving various public units. Section 3.3 will show specific technical barriers that hinder CPP in its procurement processes. An interesting feature regarding public procurement for the police is that cars are frequently bought and not leased because of the need for technical adjustments and installations in the cars. This also means that car leasing and the typical leasing situations where the responsibility for tyre replacement is outsourced are not common (see the section on leasing vehicles including tyres).

Specific application S2-Tyre procurement by cities and municipal companies for street cleaning and municipal waste disposal services: Municipal companies in the street cleaning and waste disposal sectors and cities procuring tyres for these sectors tend to use retreaded truck tyres more frequently than others. Sometimes they benefit specifically from particular functional characteristics of these tyres. Potential applications for tyres with other sustainable and circular properties, e.g., tyres with a higher proportion of recycled material than before, are less relevant in practice to date. Tyres are procured through national or European tenders, depending on the scope.

Specific application V\&L-Leasing vehicles including tyres: specific aspects concerning sustainable $\mathrm{CE}$ tyres became visible in the leasing context. The initial tyre equipment is of particular importance there. A public procurement professional (who could not participate in the interview series) stated that leased vehicles can usually be used with the initial set of tyres over the entire contract period. Leasing was particularly relevant for \#22, but various additional interviewees could share additional experiences and observations in this context.

\subsection{Barriers to Sustainable Circular Tyre Procurement}

The analysis of the interviews resulted in the identification of five groups of barriers to circular public tyre procurement. They are summarized in Table 4 and described in detail afterwards. 
Table 4. Barriers to sustainable circular public tyre procurement.

\begin{tabular}{|c|c|c|c|c|}
\hline Regulatory Barriers & Technical Barriers & $\begin{array}{c}\text { Social } \\
\text { Barriers }\end{array}$ & $\begin{array}{l}\text { Market } \\
\text { Barriers }\end{array}$ & $\begin{array}{c}\text { Environmental } \\
\text { Barriers }\end{array}$ \\
\hline $\begin{array}{l}\text { 1. Uncertainties in } \\
\text { public procurement law } \\
\text { (closely related with } \\
\text { barrier 5) }\end{array}$ & $\begin{array}{l}\text { 2. Importance of } \\
\text { product characteristics } \\
\text { that sustainability } \\
\text { measures can } \\
\text { influence }\end{array}$ & $\begin{array}{l}\text { 3. Lack of awareness } \\
\text { and trust } \\
\text { 4. Organisational } \\
\text { restrictions }\end{array}$ & $\begin{array}{l}\text { 5. Lack of standards } \\
\text { and } \\
\text { certificates } \\
\text { 6. Price and } \\
\text { inappropriate price } \\
\text { differentials } \\
\text { 7. Insufficient supply of } \\
\text { sustainable CE tyres }\end{array}$ & $\begin{array}{c}\text { 8. Insufficient } \\
\text { consideration of } \\
\text { sustainability by tyre } \\
\text { characteristics alone }\end{array}$ \\
\hline
\end{tabular}

Regulatory barriers: Uncertainty regarding procurement law emerged as an important barrier, in particular regarding big-size tyre tenders. One interviewee pointed out:

'Many points are often so soft and often resemble abstract declarations of intent so that it is problematic to convince the legal advisors in the tendering procedure.'

A closely related problem is the absence of certain standards and certificates, for example, regarding retreaded tyres (see separate section). The interviewee of \#6 described, e.g., that the exclusion of these tyres from the scope of the EU tyre label has an inhibiting effect on the procurement of retreaded tyres. A detailed discussion of the regulatory barriers and potential solutions are presented in Section 3.4.2.

Technical barriers: Technical barriers of tyre CPP refer to situations in which the requirements for tyres are so specific that there are almost no decision options for procuring sustainable $\mathrm{CE}$ tyres. This barrier relates in particular to the special safety requirements for tyres used by the police. Since tyres for police cars have to fulfil the highest performance requirements, even custom-made tyres are sometimes used, according to one interviewee. Furthermore, the interview series showed that the importance of specific product characteristics may result in concerns that sustainability measures could have undesired effects on these features. These concerns themselves also constitute a social barrier. The next section discusses social barriers in more detail. In addition, the interviewee of \#6 presented the different tyre dimensions as a technical barrier to using retreaded tyres.

Social barriers: The first social barrier, lack of awareness, often results in tyres not specified in vehicle tenders. An excerpt from the interview on case \#18 exemplifies this:

'People are very open-minded, but it's just not in their minds. I don't think they've ever thought of introducing sustainability criteria related to tyres in tenders.'

Vehicle suppliers that win the eventual bid typically deliver the cars with a standard set of tyres. When vehicles are leased, leasees are often in the situation of never having to deal with the procurement of tyres. The cars are usually returned after two years before tyre replacement is required. As the second social barrier, the change to CPP is also related to additional efforts. One interviewee highlighted this as follows:

'The (current) contracting and procurement departments cannot do this additional work.'

In addition, the interview series unveiled restrictions due to the Corona pandemic. When asked about possibilities for sustainable public procurement, one public procurement professional who could not participate in the interview series described the following situation: At the time of the call, the procurement office was facing a heavy burden due to the Corona crisis.

'We had to procure Corona protective equipment on a large scale. Other tasks, such as the consideration of sustainability aspects in procurement, could therefore not be considered appropriately.'

Market barriers: Interviewees highlighted the problem of missing standards and certificates for sustainable CE tyres (such as tyres marketed specifically as green tyres or 
retreaded tyres), for example, regarding evaluation criteria. However, in many cases, the interviewees had specific suggestions to overcome them. Therefore, the topic as a whole is presented in detail in Section 3.4.3.

Apart from this, there are particular opportunities for using retreaded tyres in the public sector in city cleaning and refuse collection. The interviewee of case \#3 even emphasised special technical advantages of these tyres:

'Retreaded tyres have reinforced carcasses. In narrow streets, the sidewalls quickly take damage from the curb. The fabric comes out of the flanks. Normal tyres would then have to be replaced. With these tyres, the sidewalls last longer. Thus, a higher running time is achieved.'

However, missing certificates and labels hinder the procurement of these tyres (see also section on regulatory barriers regarding labels in that context). As a partial solution, the interviewee of \#7 pointed out that there are already standards for retreaded tyres that can be used as a quality criterion.

Another significant market barrier consists of insufficient incentives to procure retreated tyres. The interviewee of \#7 described:

'The problem is sometimes as follows: people expect retreaded tyres to be much cheaper.

But that is not necessarily the case. What we have often had is that the purchaser then says: 'I took a new tyre, it cost only $€ 10$ more. Instead of $€ 120$, I paid $€ 130$.'

Concerns were also expressed concerning additional costs for proper disposal. The interviewee of $\# 8$, however, gave a positive statement:

'Regarding this financial argument of sustainable procurement being more expensive: if you take a closer look, the products are often cheaper, more economical.'

The inadequate offer of sustainable CE tyres as the third market barrier has two facets:

(a) Product-specific restrictions in providing appropriate choices of sustainable CE tyres: These restrictions were described primarily in the interview on case \#7. Uncountable tyres designed to respond to specific car-related requirements are on the market, and their life cycles are short according to the interviewee. The interviewee emphasized, that a circular tyre economy requires many varieties of sustainable CE tyres. All sizes and for all types of cars. Due to the current demand situation, providing sustainable CE versions for all these tyres is not attractive for the producers, according to the interviewee.

(b) Insufficient general response to tyre tenders: in addition to the problem of a limited supply of sustainable CE tyres and its impact, the interviews drew attention to another crucial issue. In general, only a few bids are received when car tyres are put out to tender. One interviewee explained, for example, that his organisation received only three bids for its last tender.

Ecological barriers: Regarding ecological barriers, it became apparent during the interviews that the sustainability assessment of tyres must include other aspects in addition to the tyre properties. This can make appropriate selections difficult. In particular, the interviewee of \#7 discussed the combination of engine performance and tyre use in terms of overall environmental impact.

\subsection{Reaction Strategies: Recommendations to Promote Tyre CPP Derived from the Interviews}

\subsubsection{Overview}

Based on the interviews, various strategies to support tyre CPP could be derived. Interviewees emphasized regulation, the development of standards and labels, and their use within regulatory instruments. Likewise, they suggested information measures and the engagement of specific target groups. The strategic recommendations are summarised in Table 5 and discussed afterwards. 
Table 5. Strategies to promote a circular tyre economy in the public procurement context.

\begin{tabular}{|c|c|c|c|}
\hline Barriers Addressed & Recommendation & Relevant Cluster & Actor \\
\hline \multicolumn{4}{|c|}{ For policymakers } \\
\hline 1,6 & $\begin{array}{l}\text { R1-Make regulatory adjustments to ensure } \\
\text { sustainable tyre CPP and contracting processes }\end{array}$ & In particular, B1 & $\mathrm{P}$ \\
\hline 1,5 & $\begin{array}{l}\text { R2-Promote the development of evaluation } \\
\text { procedures that comply with procurement law }\end{array}$ & In particular, B1 & $\mathrm{P}$ \\
\hline 1 & $\begin{array}{l}\text { R3-Declare tyres as a priority product for } \\
\text { sustainable public procurement }\end{array}$ & In particular, B1 & $\mathrm{P}$ \\
\hline 1 & R4-Promote the procurement of retreaded tyres & all & $\mathrm{P}, \mathrm{PP}$ \\
\hline 3 & $\begin{array}{c}\text { R5-Conduct a cross-procurement level information } \\
\text { campaign on sustainable CE tyres, also addressing } \\
\text { vehicle procurement }\end{array}$ & all & $\mathrm{P}$ \\
\hline 3,4 & $\begin{array}{c}\text { R6-Provide information tools with aggregated } \\
\text { content }\end{array}$ & all & $\mathrm{P}$ \\
\hline 3 & R7—Engage opinion leaders & all & $\mathrm{P}$ \\
\hline $2,3,7$ & R8-Engage vehicle, tyre, and leasing providers & All, in particular, V\&L & $\mathrm{P}$ \\
\hline all & R9-Initiate pilot projects & In particular, B1 & $\mathrm{P}, \mathrm{PP}, \mathrm{B}$ \\
\hline 4 & $\begin{array}{l}\text { R10-Check the feasibility of increasing the } \\
\text { threshold for European tenders for sustainable tyre } \\
\text { procurement }\end{array}$ & In particular, B1 & $\mathrm{P}$ \\
\hline 8 & $\begin{array}{c}\text { R11-Use the power of public procurement to move } \\
\text { further } \\
\text { towards a sustainable tyre CE }\end{array}$ & $\begin{array}{l}\text { (additional } \\
\text { recommendation) }\end{array}$ & $\mathrm{P}$ \\
\hline \multicolumn{4}{|c|}{ For procurement organisations (partly together with other stakeholder groups) } \\
\hline & R12-Implement sustainable procurement across & & \\
\hline $1,3,4$ & $\begin{array}{c}\text { your } \\
\text { organisation }\end{array}$ & all & $\mathrm{PP}$ \\
\hline 5 & $\begin{array}{l}\text { R13-Develop and use standards and certificates in } \\
\text { a targeted manner }\end{array}$ & In particular, B1 & $\mathrm{PP}, \mathrm{B}$ \\
\hline 8 & $\begin{array}{l}\text { R14-In addition to the focus on sustainability in } \\
\text { product characteristics, include CE compliant } \\
\text { requirements concerning the disposal } \\
\text { (see also suggestions in the section for policymakers) }\end{array}$ & all & $\mathrm{PP}$ \\
\hline
\end{tabular}

\subsubsection{Recommendations for Policymakers}

Based on the interview series, eleven recommendations for policy makers were derived:

1. Make regulatory adjustments to ensure sustainable tyre CPP and contracting processes: The interview series showed a need for changes in legislation. In particular, the interviews on \#2 and \#5 referred to this. Two options for action were suggested in the interview on \#2: introduce a certificate that complies with procurement law and can be made a requirement in procurement processes, or grant discretion to the contracting authorities if there is no established certificate. Another option is to make justification mandatory for non-sustainable publicly procured tyres. The reference to this recommendation was made in the interview on \#5 to similar procedures for the use of electric vehicles.

In several interviews, reference was made to service directives or council resolutions: as a recommendation and concerning plans for a specific organisation-wide pilot project in the interview on case \#17. It is also important to learn from good practice in other areas of public procurement.

Points of reference for this were given in particular in two interviews which highlighted the Federal Ministry's for Economic Affairs and Energy (BMWi) initiative to stimulate the development of specifications on energy emissions in the VgV. Likewise, the interviewee of \#14 recommended council resolutions on city levels to promote sustainability and CPP. 
As an additional measure, the interviewee of \#5 referred to price aspects and suggested financial support for sustainable CE tyre procurement, comparable with the support for buying electric vehicles: 'You can see that since the government has subsidised electric vehicles, there are more and more sales of them.' In this context, the new CE Action Plan [46] recommends 'rewarding products based on their different sustainability performance, including by linking high-performance levels with incentives.'

An additional suggestion related to recommendation R1 is to provide special conditions for small procurement volumes to avoid an unnecessary burden. This is also in line with Section 7 of the Federal Budget Code (BHO) on economy and thrift, cost, and performance accounting [13].

2. Promote the development of evaluation procedures that comply with procurement law: The need for evaluation procedures that comply with procurement law was mentioned in particular in the interview on \#2. Emphasis was placed on the desire for market-recognised assessment procedures. One option for their establishment is standardisation. Similarly, the interviewee of \#6 addressed the need to specify law-compliant evaluation procedures due to uncertainties in law implementation. Specific labelling strategies regarding retreaded tyres were, for example, suggested by the interviewee of \#16 and will be described in the separate section on these instruments below. In addition, the interviewee of \#18 underlined the need for a trustworthy body to support the work with labels and standards:

'(a body) that confirms: if you take the label, you can rely on it because it is not possible for (public procurement professionals) to compare all the labels with each other. Public procurement professionals cannot do that. They do not have the time.'

Promoting the development of the evaluation process can rely, e.g., on standardisation mandates and policies on labelling as practiced in the past. The establishment of the EU tyre label provides an example for this approach. (The EU tyre label is mainly focussed on fuel efficiency, road safety, and external rolling noise, but not specifically on circular material aspects.)

3. Declare tyres as a priority product for sustainable public procurement: According to [54], sustainable procurement requires documented prioritisation. Multiple SPP 'priority products' have already been defined and published on the website of Germany's national office for sustainable procurement (KNB). Sustainable CE tyres can only suitably penetrate public procurement if they are also defined as a priority product, cf. interview on \#20.

4. Promote the procurement of retreaded tyres: The recommendation regarding retreaded tyres includes both currently available tyres and the results of future-oriented projects, e.g., from Continental (see, e. g. [32]), which promise further improvements of tyre properties.

Retreaded tyres appear to be attractive when speed is less relevant. Concerning large order volumes, the interviewee of \#16 described that retreaded tyres are promoted by an increased threshold for EU tenders in favour of a national tender based on the declaration as a 'social service.' In addition, two recommendations were derived to promote sustainable $\mathrm{CPP}$ also at the national level for retreaded tyres. The recommendation to policymakers is: advance a label for retreaded tyres at the European level.

A related recommendation to public procurement professionals has the following three elements: intensify the focus on opportunities to purchase sustainable CE tyres concerning retreaded tyres, as previously discussed, introduce mandatory justification if sustainable tyres are not purchased, and purposefully use standards in describing requirements for retreaded tyres.

5. Conduct a cross-procurement level information campaign on sustainable tyres, also addressing vehicle procurement: The interview series clearly showed an information deficit regarding sustainable $C E$ tyres. As one interviewee stated: 
'We haven't heard about sustainable tyres yet. Advertising is required. Advertising is important. [ ... ] If there is something, we (will adopt it), but someone has to say there is something. [ ... ] It would be interesting to advertise recycled tyres, but if there are any, I don't know.'

The interviewees of \#16 and \#17 emphasised the importance of raising awareness even more.

From the interviews on tyre procurement framework agreements, the importance of different actors in the tyre procurement process and their various ways to influence tyre selection concerning sustainable $\mathrm{CE}$ aspects became clear. The managers of tenders and framework agreements can only prescribe sustainable CE features with low specifications. Therefore, it is important to communicate this challenge clearly to other organisational units involved, e.g., in fleet management, and explicitly draw their attention to sustainability issues. The specification of sustainable CE aspects requires the commitment of further stakeholders entrusted with the specification and use of tyres besides the central procurement units.

The interviewee of \#11 addressed the inclusion of CE and sustainability topics in the mandatory training courses for drivers of trucks over 12 tons. In addition, it was suggested to offer this training in shorter intervals, and also for drivers of lighter vehicles. Likewise, providing instructional videos for companies with fleets was advised. At the same time, it was described in the interview on \#10, for example, that tyres as a whole often play a subordinate role when vehicles are put out to tender. Appropriate awareness-raising is needed here. Additional suggestions for incentives included, among others, offering the opportunity of a sample use of sustainable CE tyres to raise trust in these tyres. Especially concerning organisations with a tyre demand of several thousand units per year, this would have great potential.

6. Provide information tools with aggregated content: The interviewee of \#18 described the need for appropriate IT tools illustratively:

'A small survey we started revealed that procurement professionals would like to have (and need) specific information. And a tool like this would be really, really helpful. [ ... ] The question about product information and tools was based on a catalogue with all kinds of options. From a list, a maximum of three aspects could be selected as priorities. Tools and information were $25 \%$ among the first three, and thus right at the top, they were named most frequently.'

The ConCirMy project addresses this need specifically by developing an IT tool for selecting CE tyres and configurating cars with these products.

7. Engage opinion leaders: Concerning the involvement of opinion leaders, the German automobile club ADAC, Europe's largest motoring association, was considered specifically. Various interviewees mentioned the ADAC as a frequently used source of information on tyres. The desire for ADAC rankings of tyres according to their sustainability and circularity properties was explicitly described in the interview on \#2. Currently, only the rolling resistance affecting fuel consumption is considered: see, e.g., [55]. The interviewee of case \#9, on the other hand, regarded it as crucial that the tests are not conducted by ADAC but by an independent body. A combination of offers from both groups of players could provide particular added value.

8. Engage vehicle, tyre, and leasing providers: The interview series led to specific individual recommendations regarding three particular stakeholders: vehicle, tyre, and leasing providers. First, it is crucial to raise the interest of car dealers and leasing companies in tyre-related sustainability topics. One existing barrier to the spread of sustainable CE tyres mentioned in particular in the interviews on cases \#5 and \#14 is leasing practices, linked with a lack of the users' consideration of tyres. Since users of leased vehicles are unlikely to purchase tyres themselves later on, it is essential that leasing providers offer suitable options. Second, regarding the problem of retreaded tyres, different carcasses mentioned in the interview on case \#16, targeted collection of tyres could provide a solution, e.g., when 
tyres are procured and disposed based on master contracts. A specific goal regarding tyre suppliers concerns the suppliers of retreaded tyres who cannot offer retreaded tyres for all dimensions due to the large variety of tyres and handle the diversity of tyre dimensions available. Innovative sorting solutions seem to be necessary in this context.

9. Initiate pilot projects: One interviewee explained in detail how pilot projects are used for SPP implementation. This person suggested pilot projects also explicitly for sustainable tyre CPP. Likewise, the interviewee of case \#18 provided an illustrative example of such a project on a municipality level, although without a nationwide reach and without a specific tyre focus. A specific element in the pilot project presented by [54] is the work with assessment components for sustainability. Two interviewees addressed this aspect specifically. A resulting recommendation is to initiate more pilot projects for sustainable tyre CPP to gain experience with sustainable procurement in this area.

10. Check the feasibility of increasing the threshold for European tenders for sustainable tyre procurement: The recommendation to increase the threshold value for sustainably procured products analogous to social services treatment was described in detail by one interviewee. The interviewee added the explanation that EU law attractively considers retreads as social services. Extending a similar principle to all sustainable products was recommended:

'Retreading is considered an area of social services. [ . . . ] The EU has declared certain services as social services in its last directive. [ ... ] There are special regulations there, and less competition is desired. [ ... ] Thereby, there is a blatantly higher threshold for EU procurement, i.e., it is longer tenderable domestically: the limit is not $€ 214,000$, but $€ 750,000$. [ . . ] (AND there are) simplified procedures, i.e., one can choose e.g., other or easier types of procedures, other negotiation procedures, consider other award criteria that are company-related! From my point of view, it would be generally desirable to say: I facilitate SPP [ ... ] if you procure environmentally friendly, then you get facilitations, then you do not have to tender EU-wide or only from a higher threshold value, or you are allowed to use other criteria that would otherwise not be allowed, or you are allowed to set other deadlines [... ]. I think what also needs to be changed legislatively: currently, there is a total focus in public procurement law on the subject matter of the service. [ . . . ] Many things linked with sustainability are not directly related to the product or service itself. However, sustainability is often practiced on the company level [ . . . ]. You could argue, for example, that a member of the Fair Wear Foundation certainly has a proportion of fairly traded products. (...) If you can say, OK, that increases the probability that the product, which I procure, is also fairly traded, [ . . ] that (information) would be sufficient, that would (facilitate SPP/CPP a lot).'

According to the interview on case \#16, the EU reforms the Public Procurement Directives every ten years, with the next reform expected in 2024.

The higher thresholds for EU tenders in the procurement of retreaded tyres are justified by social aspects in the production of these tyres. Higher thresholds for sustainable tyres should also pay particular attention to social sustainability based on ILO core working standards. In addition, environmentally sustainability and circularity should be ensured. Assuring such kind of sustainability would also justify the procurement of tyres nationally instead of procurement on the EU level.

Regarding this issue in general, refs. [56,57] highlight the risk that higher discretion for public procurement officials does not always mean better outcomes. In the tyre context, the example of retreaded tyres has already proved the suitability of this approach. To analyse the potential impact of the recommendation in the new context further, the concept of regulatory experiments, also called 'regulatory sandboxes' [58,59] could be applied. The German project 'Regulatorische Experimentierräume für die reflexive und adaptive Governance von Innovationen' (REraGI), English: 'Regulatory experimentation spaces for the reflective and adaptive governance of innovations' provides an example for such an experimental measure. Based on Germany's federal structure, a Federal State could be choosen as a pilot region to analyse the suitability of this approach further. 
One remaining issue is, however, economic sustainability. Price efficiency is of particular importance in the public sector. EU tendering may facilitate the receipt of more offers and also raise the likelihood of receiving more bits with attractive prices. Therefore, this measure should only be implemented for a short period of time as an initial ignition for the market for sustainable CE tyres.

11. Use the power of public procurement to move further towards a sustainable tyre CE: Numerous examples for using public procurement to promote sustainable products in general were part of the interview on \#2. In the interviews on \#5 and \#7, retreaded tyres were discussed in this context. Currently, the market for these tyres is small. Various retreaded tyres are niche products, and prices are not attractive. Developing the market to a mainstream market with the help of public demand could also influence the prices attractively, leading to more demand and even more market growth as a consequence.

\subsubsection{Recommendations for Procurement Organisations}

Three recommendations were developed for procurement organisations. The recommendation regarding standards and certificates explicitly requires the involvement of other stakeholders. In particular, the creation of certificates and labels may need regulatory support, e.g., similar to the EU tyre label's development (see also the first recommendation for policymakers regarding necessary regulatory adjustments to support CPP).

1. Implement sustainable procurement across your organisation: The interviewee of \#7 described the importance of embedding sustainability as centrally and early as possible in the procurement process:

'In (our Federal State), recycling is a very big issue. We put a lot of emphasis on supply chains and recycling chains in the tendering process. (... ) There are European standards and specifications from us in the central purchasing department that use these criteria. Whoever supplies us with tyres (for example) must also be able to dispose of them. There is an obligation which is part of the tendering process. It is important to do this already during the tendering process because, in day-to-day business, a colleague (who needs to buy a set tyres) would not be able to take care of the disposal chains. We attach a great deal of importance to presenting the subject of supply chain and disposal as early as the tendering stage [ ... ].'

Specific measures were developed in the interview on case \#18:

'We are in the process of developing regulated structures to address this (sustainability) again and again with the individual procurers [... ]. A steering group has just been formed; it is very broadly based, from the staff council to the finance department. This working group is drawing up a particular set of instructions that will make sustainable procurement the norm. This is a pillar where it is said that sustainable tenders will always be issued. If sustainable procurement is not possible for any reason, this must be justified separately. That is the aim of the service directive, which is on its way. Of course, the top management still has to approve the concept. [ . . ] But it is good that we have set up this group so broadly because this also leads to a high level of acceptance in the administration [ ... ]. The plan is to have a trial run in the core administration first and expand the concept.'

In addition, interviewee of case \#18 highlighted the importance of appropriate staffing and creating a position for an employee responsible for sustainability issues.

2. Develop and use standards and certificates in a targeted manner: The need for standards and certificates was addressed explicitly by the interview partners. An example of this is the interviewee of \#2 who suggested a certificate that complies with procurement law and with complying criteria specifically. Altogether, four main standardisation topics were derived from the interview series according to Figure 3. 


\section{RECYCLED CONTENT}

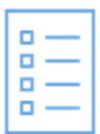

'A standard for the declaration of the recycled content of a tyre.' (\#1)

' $\mathrm{CO}_{2}$ footprint $[\ldots]$ according to uniform measurement procedures.' (\#2)

(a similar suggestion was given by I10, see below)

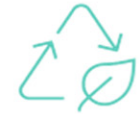

\section{SUSTAINABILITY ASSESSMENT}

'Procedure for comparison to conventional tyres on $\mathrm{CO}_{2}$, etc.' (\#10)

Enabling comparisons between retreaded and conventional tyres $(\# 20)$

\section{COMPARISON}

Figure 3. Mentioned needs for standardisation to support a tyre CE.

In addition, the interviewee of \#16 described the need for an EU definition of sustainability for procurement. One aspect was also the definition of a sustainably acting institution, somehow 'above' the consideration of specific sustainable products. One possibility for providing such recognised definitions would lie in standardisation. A discussion of Table 5 is provided in Section 4.

Impulses for certification included both a general label for sustainable tyres and a specific solution for retreaded tyres. In general, six aspects were discussed according to Figure 4.

\section{Labelling and certification needs to support a tyre CE}

\section{Sustainable tyres in general}

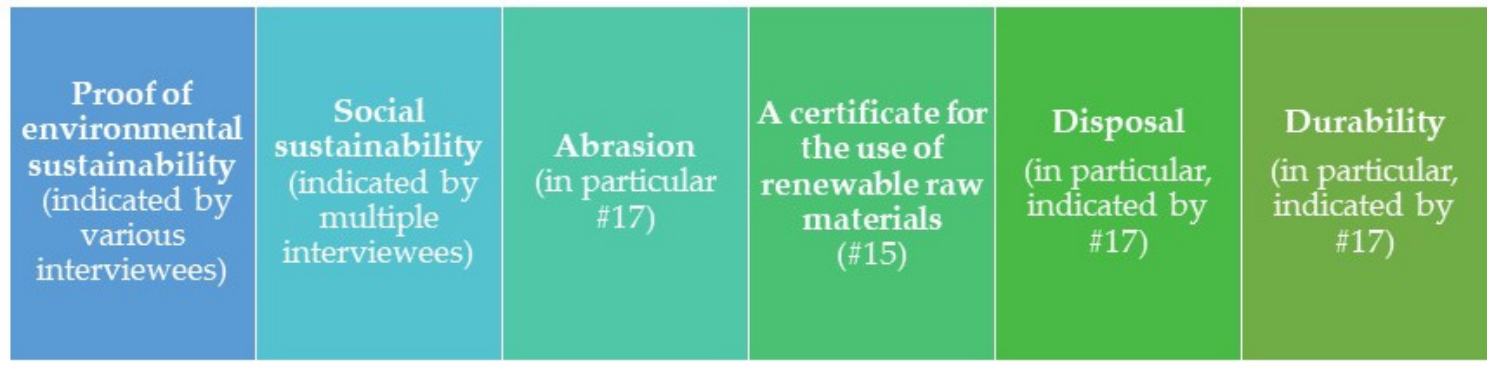

\section{Retreaded tyres}

Standardisation of European test procedures (\#12 and \#16)
Certificate or label with

European validity (\#16)

Figure 4. Labelling and certification needs to support a tyre CE according to the interviews. 
Facets of the need 'proof of environmental sustainability' included, e.g., 'environmental sustainability and a certificate for renewable raw materials,' 'consideration for longevity' (interview on \#15), 'a certificate for social criteria and energy' (interview on \#20) as well as sustainable rubber cultivation in the cases \#2,\#6, and \#16. Social sustainability is understood by these interviewees as, e.g., no child labour and sustainable rubber cultivation. Specifically, three interviewees mentioned sustainability issues of rubber production. At the same time, it was mentioned that self-declaration can provide proof as an alternative to a certificate.

In addition to the broader certification topics, two specific issues were identified. The first referred to retreaded tyres, specifically the standardisation of European test procedures according to the interviews on cases \#2 and \#6 and a certificate or label with European validity according to the interviewee on \#6. The other specific certification aspect is disposal, which is considered in the next section.

3. In addition to the sustainability focus on product properties, include CE compliant requirements concerning the disposal: Two identified barriers showed that sustainability goals could be subject to limits concerning realisable tyre properties. Further opportunities for circularity-oriented action are offered by disposal. The recommendation on disposal requirements was derived from plans in the interviews on cases \#5 and \#6.

In the first stage, proper disposal is to be required. In the second stage, a certificate on sustainable disposal can be required in line with interview on \#6. One advantage of this option for action that promotes CE is that procurers can act in the sense of CE without having to make any changes to the tyres used.

\section{Summary of Results}

Based on GT principles, this article aimed to provide answers to the following questions:

(1) Which procedures are mainly applied to procure tyres and which selection criteria are mainly adopted in the procurement processes?

(2) Which barriers exist to take greater account of the United Nations Sustainable Development Goals (UN SDGs) and the German Circular Economy Act (Kreislaufwirtschaftsgesetz, KrWG) in the procurement of vehicular tyres?

(3) In response to the barriers mentioned in question 2, which strategies could support the procurement of sustainable CE tyres?

The GT model was specified accordingly. On this basis, the GT element 'Causal condition' and its specification 'various types of procedures in public tyre procurement, $\mathrm{CE}$ regulation meets traditional procurement processes' reflected question 1 , the element phenomenon referred to question 2 and the element reaction strategies to question 3.

In response to question 1 , our analysis identified six clusters with specific tyre procurement characteristics: three basic types, which differ regarding the extent and complexity of the procurement processes, tyre procurement for specific applications as well as tyre procurement as a part of vehicle procurement and leasing. All kinds of formal procurement processes were observed: from small orders to large EU tenders of several hundred thousand Euros. Current tyre selection criteria are, in particular, price, mileage, and safety, although the EU tyre label is also partly used. If retreaded tyres are bought, the main reasons are specific functional characteristics and the price; sustainability considerations are less important. Based on the degree of tyre CPP and CPP opportunities, four types of procurement organisations were identified.

Question 2 led to the identification of regulatory, technical, social, market, and ecological barriers. 
Question 3, dedicated to appropriate CPP strategies, served as the foundation for creating 14 recommendations specified in Table 5. They include EU-level, national and organisation-level instruments. One suggestion referred to two specific quality infrastructure elements, including four standardisation needs and eight labelling topics.

An example for an EU-level measure is a possible increase of the threshold for European tenders favouring the right to practice a more convenient procurement on a national level if CPP takes place. Examples of national CPP support measures are the declaration of tyres as a CPP priority product and information campaigns. An organisation-level instrument is, e.g., the implementation of organization-wide SPP with CPP on top. Good practice was shown by an organisation-wide project in \#16, which aims to make sustainable public procurement the standard procurement process for all products.

\section{Discussion and Conclusions}

\subsection{Contribution to Research and Practice}

This article provided insight into an under-represented public procurement topic. While certain scientific insight in successful SPP, GPP, and partly CPP is already available, indepth knowledge is still missing in various market areas. In this context, the management of tyres in a way that is fully in line with CE goals is an important task. This article analysed suitable strategies to implement circular public tyre procurement and aimed to enrich CPP research by in-depth product-specific analyses and to promote the further development of a tyre CE. Due to GT principles, this article's GT result is already empirically proved by the interdependence of empiricism and theory, cf. [49,50]. This proof means that further variations of the GT discovered later can be inserted as further developments of this original theory, cf. [47].

This article identified five barrier types of sustainable tyre CPP which are of regulatory, technical, social, market, and ecological nature. With a broader scope on the CE, [14] discovered four barrier types: cultural, regulatory, market, and technological barriers. Their work and the social and cultural barriers identified in this paper have similarities, highlighting the relevance of [14]'s findings also on a specific product level. This observation applies in particular to the awareness aspect. However, while [14] focus on consumers' awareness, this paper refers to the awareness of $\mathrm{CE}$ tyre issues by public procurement professionals. Likewise, [14]'s market barrier and this article's counterpart's features have similarities, e.g., concerning limited funding. However, our work shows the specific barriers of public procurement professionals in the tyre context while the [14] market barrier has a slightly stronger focus on the market's supply side. In contrast to [14], this article identified not only missing standards as a CE barrier, but also highlighted the need for appropriate labelling. In addition, it provides solutions for both issues. As an additional contribution compared with [14], this article identified also an ecological barrier of a tyre CE.

Fourteen recommendations were derived from this research, also encouraging the development and usage of standards and certificates. In this context, four specific standardisation topics and eight labelling topics were mentioned and will be further pursued by the ConCirMy project. The standardisation needs described by the interviewees were discussed with a standardisation expert. The specification of the tyres' recycled content includes two aspects. The specification of minimum percentages could only be enforced by legislation. Open questions, which may be addressed by standardisation are, however, e.g., how the quality 'recycled' is defined, how the recycled content is declared and whether it refers to the tyre or parts of it.

Important standards addressing the needs ' $\mathrm{CO}_{2}$ footprint $[\ldots$ ] according to uniform measurement procedures' and 'procedure for comparison to conventional tyres on $\mathrm{CO}_{2}$, etc.' are the ISO standard 14000 and the ISO 14000 standards series as a whole. However, more product-specific specifications may be necessary to specify LCAs and the carbon footprint of tyres. A PCR (product category rule for type III environmental declarations) has been developed for tyres by the International EPD system [60] and two tyre EPDs have been published to date (28 September 2021). 
These standards may also provide a suitable foundation for comparisons with conventional tyres. If additional sustainability characteristics shall be compared, however, additional specification may become necessary. Regarding comparisons between retreaded tyres and conventional tyres, safety is an important aspect. Both types of tyres can be evaluated according to these standards and compared afterwards. However, more guidance may be necessary to decide which parameters shall be used and how the comparisons take place.

Various recommendations derived from this study refer to specific information measures. In addition, several previously identified aspects were emphasized as critical issues for sustainable CE tyre procurement. They refer, in particular, to recommendations R1, R6, $\mathrm{R} 9, \mathrm{R} 11$, and R13.

Hartley et al. [16] identified six promising policy changes to support the transitioning towards a CE, which were, besides (a) an expansion of CPP: (b) more advanced standards in production, (c) tax relief for circular products, (d) deregulation in the area of waste trading and support trading by digital platforms, (e) support for eco-industrial parks and f) awareness campaigns. This GT-based study showed that links between these measures exist. It emphasised the importance of standards, financial promotion of circular products, platforms, and awareness campaigns with their potential, stimulating effect on CPP. For this reason, standards, virtual platforms, and awareness campaigns require specific consideration. Regulatory adjustments, however, seem to be the most important driving force for the future's CPP. Future research on CPP will provide more insight into the contribution of each instrument.

This article explicitly built on [3]'s overview of state of the art in SPP and extended the insights by GT-based findings on a specific product category. Sönnichsen and Clement [21] describe that CPP is more established in large organisations than in smaller ones. In the context of this study, size was significant for the procurement volumes, meaning that sustainability was more important for extensive procurement processes than the purchase of single tyre sets only.

Sönnichsen and Clement [21] also highlighted the importance of awareness and experience, which were identified as more important factors for implementing CPP and dissemination than economic resources. Likewise, the information by the interviewees led to a specific recommendation for awareness campaigns on sustainable CE tyres. In addition, [21] emphasised that the education of purchasing professionals in the use of CPP criteria is crucial to magnifying opportunities. Knowledge of sustainable CE products and information on the appropriate use of procurement criteria appeared to be important in the interviews as well. Another factor highlighted by [21] is the dissemination of best practices. Likewise, the interview series emphasised the use of good practice explicitly. Finally, [21] referred to information tools as process enablers, also in the form of ecolabels, life cycle assessment, and costing. Since this was also underlined in the interview series, the ConCirMy project has two aims in this context: first, providing an information platform for sustainable circular tyre procurement, and second, formulating recommendations for stimulating sustainable public procurement of tyres, such as appropriate labelling activities and policy recommendations.

\subsection{Limitations and Recommendations for Further Research}

This article deals with circular public tyre procurement based on the GT model with the elements causal condition, context, phenomenon, reaction strategies, and consequences. The element 'consequences' describes the desired public tyre procurement of the future with changed priorities and framework conditions and more sustainable tyre CPP which influences the market as a whole. Consequences can be analysed from short to mediumand long-term perspectives. As explained in the next paragraph, a period of five years provides appropriate framework conditions for next research steps. On this basis, a fundamental question regarding the future nature of the GT element 'consequences' is 
which characteristics the tyre market will have in five years. This question is linked with three sub-questions.

The first sub-question concerns the degree of stakeholder engagement for sustainable tyres reached by 2026 and the drivers which will shape the character of this future market. In addition, one of our recommendations referred to standardisation, which means reaching agreements on particular specifications. An important second question is, therefore, which agreements will be reached to support $\mathrm{CE}$ tyres and whose interests were addressed the most. Therefore, this sustainability aspect also provides an interesting topic for standardisation research. The typical standardisation period of four years led also to our above-mentioned specification of an appropriate investigation period of short-term changes in the tyre market for all three sub-questions. The third sub-question is whether public procurers' purchasing power could be used to stimulate the development of sustainable tyres significantly and, if yes, which lessons can be used for other sustainable and/or innovative products. Regarding the market as a whole, the potential effects of standardisation, visible from the fourth year on, have to be considered specifically. Therefore, five years provide an appropriate frame for analysing changes in the market the first time. An appropriate analysis of market changes also requires a specification of suitable parameters and a diligent description of their current characteristics. An example for analysing the effect of green public procurement policies in a specific product area is provided by [61].

In addition, the research gaps regarding the Grounded Theory element 'consequences,' limitations also exist in a broader context. At the beginning, the seven tyre management options which can support the realisation of a CE according to [7] were presented. This article focused mainly on options 4 or 6 . Another option is, e.g., 'Refuse via reducing vehicle ownership and using alternative modes of transport.' Indeed, some public managers consider this option. In particular, in rural areas, however, these options appear to be difficult. Nevertheless, more insight into successful implementations of these options seems to be useful. Therefore, this aspect is also a topic for further research.

As we wrap up this paper, the World Climate Change Conference is taking place in Glasgow. It aims to substantially contribute to the global sustainability strategy and realize a lasting impact on future climate development. Progress in a wide range of socio-technical areas is desired. This progress can also further develop the framework conditions for sustainable tyres post-2021. Scholars from various disciplines such as economics and standards research are invited to explore the future of sustainable tyres and sustainable mobility as a whole in more detail.

Author Contributions: Conceptualization: S.W., Investigation: S.W., Methodology: S.W., Writingoriginal draft: S.W., Writing—review and editing: S.W., R.S., R.G.S. and S.H. All authors have read and agreed to the published version of the manuscript.

Funding: We acknowledge the support by the German Federal Ministry of Education and Research (BMBF) (ConCirMy project, measure ReziProK, funding No. 033R236E), the German Research Foundation and the Open Access Publication Fund of TU Berlin.

Institutional Review Board Statement: This study relied on proven data management techniques of our institute. The article presented experts opinions and does not contain ethical critical data. A cross-check by the team confirmed that the article does not contain information which would make the interviewees identifiable. Ethical review and approval were waived.

Informed Consent Statement: Patient consent is not applicable to/required for this study since no patients were interviewed.

Data Availability Statement: Raw data is stored at TU Berlin according to our privacy declaration, according to which we treat personal data confidentially.

Conflicts of Interest: The authors declare no conflict of interest. 


\section{Appendix A. Interview Guide}

Framework conditions for sustainable procurement of car tyres in line with the goals of the circular economy

The BMBF-funded ConCirMy project (https:/ / concirmy.org/) is investigating whether and how car tyres can be optimised in line with the goals of a circular economy while maintaining high functional quality. A tool is being developed to provide the various actors in the supply chain with information on environmental compatibility for (purchasing) decisions. The following questions are intended to deepen the framework for public procurement of sustainable tyres.

(1) Which procedures do you use for tyre procurement?

(2) What software do you use for procurement processes?

(3) Which decision criteria/indicators are primarily used for the procurement of tyres (e.g., price, mileage, sustainability in production, recycling share, existence of certain certificates)?

(4) How do you analyse the market to generally determine the market supply for the preparation of tenders?

(5) Do you have experience with the procurement of retreaded tyres?

(6) If so, in what area have you procured retreaded tyres?

(7) How is tyre return organised in your organisation?

(8) To what extent are there plans in your organisation to take stronger account of the United Nations Sustainable Development Goals and the Circular Economy Act in the procurement of car tyres?

(9) What incentives could support implementation?

(10) Is there a need to increase legal certainty for the procurement of circular economy tyres, e.g., tyres that are proportionally made of recycled material or recyclable tyres?

(11) What would be promising application scenarios for ConCirMy's tyre configuration software for you (example: market exploration)?

(12) In your view, which tyres should have the first priority regarding circular economy with policymakers: (a) tyres of (new) vehicles, e.g., electric vehicles or (b) tyres of the tyre replacement business?

(13) What preferences would you have to obtain qualitative or quantitative information on the environmental and social performance of sustainable tyres, e.g., in terms of indicators, limits, and certificates?

(14) What recommendations or needs do you have regarding norms, standards, and la-bels/certification for sustainable tyres?

(15) Do you have any further advice for our project?

Supplementary information:

How many tyres on average do you procure annually, according to your estimation?

\section{Appendix B}

Table A1. Overview of the Interviewees' Framework Conditions.

\begin{tabular}{ccc}
\hline Case & $\begin{array}{c}\text { Tyre Demandper } \\
\text { Year/Contract Period (Range) }\end{array}$ & Type of Procedure for Tyre Procurement \\
\hline 1 & N.a. & N.a. \\
2 & $5001-10,000$ & EU tender/4-year framework contract \\
3 & $251-500$ & Public tender national \\
4 & several thousand & EU tender \\
5 & tyres in 3 years & EU tender/4-year framework contract \\
\hline
\end{tabular}


Table A1. Cont.

\begin{tabular}{|c|c|c|}
\hline Case & $\begin{array}{c}\text { Tyre Demandper } \\
\text { Year/Contract Period (Range) }\end{array}$ & Type of Procedure for Tyre Procurement \\
\hline 6 & $5001-10,000$ & EU tender/4-year framework contract \\
\hline 7 & $1001-5000$ & $\begin{array}{l}\text { Based on framework contract individual } \\
\text { selection }\end{array}$ \\
\hline 8 & $>10,000$ & $\begin{array}{l}\text { Public invitation to tender nationally in } \\
\text { 'open procedure' }\end{array}$ \\
\hline 9 & $<100$ & Orders from a local dealer \\
\hline 10 & $<100$ & Free hand award \\
\hline 11 & $101-250$ & Public tender national \\
\hline 12 & $101-250$ & Public tender national \\
\hline 13 & $<100$ & Orders (no framework agreements) \\
\hline 14 & N.a. but around 700 vehicles & Maintenance contracts of vehicle suppliers \\
\hline 15 & $<100$ & Orders for individual needs \\
\hline 16 & $251-500 *$ & $\begin{array}{l}\text { (usually EU) vehicle tenders, especially for } \\
\text { fire departments, heavy vehicles }\end{array}$ \\
\hline 17 & $<100$ & Individual orders \\
\hline 18 & $<100$ & Orders \\
\hline 19 & $<100$ & Orders \\
\hline 20 & 501-1000 & $\begin{array}{c}\text { Div. procedures, often direct awards of } \\
\text { contracts }\end{array}$ \\
\hline 21 & $251-500$ & Public tender national \\
\hline 22 & $-(\approx 100$ leased vehicles $)$ & Public invitation to tender for leasing \\
\hline
\end{tabular}

\section{References}

1. Genan. Nachhaltiges Altreifenrecycling. 2019. Available online: https:/ /www.genan.de/ (accessed on 30 September 2021).

2. Genan. Jahresbericht 2020: Genan Gelingt Konsolidierung in Einem von der Coronapandemie Geprägten Jahr. 2021. Available online: https://www.genan.de/wp-content/uploads/2021/05/Pressemitteilung_Jahresbericht-2020_Genan-gelingtKonsolidierung-in-einem-von-der-Coronapandemie-gepragten-Jahr_07052021.pdf (accessed on 30 September 2021).

3. Grammelis, P.; Margaritis, N.; Dallas, P.; Rakopoulos, D.; Mavrias, G. A Review on Management of End of Life Tires (ELTs) and Alternative Uses of Textile Fibers. Energies 2021, 14, 571. [CrossRef]

4. Council of the European Union. Council Directive 1999/31/EC of 26 April 1999 on the landfill of waste. Off. J. Eur. Union 1999, L182, 0001-0019.

5. MacArthur, F.E. Towards the Circular Economy Vol. 1: An Economic and Business Rationale for An Accelerated Transition. 2013. Available online: https: / / circular-impacts.eu/library/1347 (accessed on 30 September 2021).

6. Kirchherr, J.; Reike, D.; Hekkert, M. Conceptualizing the circular economy: An analysis of 114 definitions. Resour. Conserv. Recycl. 2017, 127, 221-232. [CrossRef]

7. Campbell-Johnston, K.; Friant, M.C.; Thapa, K.; Lakerveld, D.; Vermeulen, W.J. How circular is your tyre: Experiences with extended producer responsibility from a circular economy perspective. J. Clean. Prod. 2020, 270, 122042. [CrossRef]

8. Dabic-Ostojic, S.; Simic, V.; Miljuš, M. Used Tire Management: An Overview. Part I. In Proceedings of the 3rd Logistics International Conference, Belgrade, Serbia, 25-27 May 2017.

9. Stanojević, D.D.; Rajković, M.B.; Tošković, D.V. Management of used tires, accomplishments in the world, and situation in Serbia. Chem. Ind. 2011, 65, 727-738. [CrossRef]

10. ADB/ILO. Core Labour Standards Handbook. 2006. Available online: https://www.ilo.org/wcmsp5/groups/public/---asia/--ro-bangkok/---ilo-manila/documents/publication/wcms_126253.pdf (accessed on 30 September 2021).

11. Bosio, E.; Djankov, S.; Glaeser, E.; Shleifer, A. Public Procurement in Law and Practice. Available online: https://scholar.harvard. edu/files/shleifer/files/public_procurement_law_practice_11_may_2020.pdf (accessed on 30 September 2021).

12. Edler, J.; Georghiou, L. Public procurement and innovation-Resurrecting the demand side. Res. Policy 2007, 36, 949-963. [CrossRef]

13. BMU. Umweltfreundliche Öffentliche Beschaffung. 2020. Available online: https://www.bmu.de/themen/wirtschaft-produkteressourcen-tourismus/produkte-und-konsum/umweltfreundliche-beschaffung/ (accessed on 27 September 2021).

14. Kirchherr, J.; Piscicelli, L.; Bour, R.; Kostense-Smit, E.; Muller, J.; Huibrechtse-Truijens, A.; Hekkert, M. Barriers to the Circular Economy: Evidence From the European Union (EU). Ecol. Econ. 2018, 150, 264-272. [CrossRef]

15. European Commission. Public Procurement for a Circular Economy: Good Practice and Guidance. 2017. Available online: https: / / ec.europa.eu/environment/gpp/pubs_en.htm (accessed on 30 September 2021).

16. Hartley, K.; van Santen, R.; Kirchherr, J. Policies for transitioning towards a circular economy: Expectations from the European Union (EU). Resour. Conserv. Recycl. 2020, 155, 104634. [CrossRef] 
17. Campbell-Johnston, K.; Cate, J.T.; Elfering-Petrovic, M.; Gupta, J. City level circular transitions: Barriers and limits in Amsterdam, Utrecht and The Hague. J. Clean. Prod. 2019, 235, 1232-1239. [CrossRef]

18. Klein, N.; Ramos, T.; Deutz, P. Circular Economy Practices and Strategies in Public Sector Organizations: An Integrative Review. Sustainability 2020, 12, 4181. [CrossRef]

19. Lăzăroiu, G.; Ionescu, L.; Uță, C.; Hurloiu, I.; Andronie, M.; Dijmărescu, I. Environmentally Responsible Behavior and Sustainability Policy Adoption in Green Public Procurement. Sustainability 2020, 12, 2110. [CrossRef]

20. Siminicg, M.; Avram, M.; Popescu, L.; Avram, R.L. The Adoption of National Green Procurement Plans from the Perspective of Circular Economy. Amfiteatru Econ. 2020, 22, 15-27. [CrossRef]

21. Sönnichsen, S.D.; Clement, J. Review of green and sustainable public procurement: Towards circular public procurement. J. Clean Prod. 2020, 245. [CrossRef]

22. Kristensen, H.S.; Mosgaard, M.A.; Remmen, A. Circular public procurement practices in Danish municipalities. J. Clean. Prod. 2021, 281, 124962. [CrossRef]

23. Alhola, K.; Ryding, S.O.; Salmenperä, H.; Busch, N.J. Exploiting the Potential of Public Procurement: Opportunities for Circular Economy. J. Ind. Ecol. 2018, 23, 96-109. [CrossRef]

24. Soto, T.; Escrig, T.; Serrano-Lanzarote, B.; Matarredona, N. An Approach to Environmental Criteria in Public Procurement for the Renovation of Buildings in Spain. Sustainability 2020, 12, 7590. [CrossRef]

25. Bao, Z.; Lu, W.; Chi, B.; Yuan, H.; Hao, J. Procurement innovation for a circular economy of construction and demolition waste: Lessons learnt from Suzhou, China. Waste Manag. 2019, 99, 12-21. [CrossRef] [PubMed]

26. Segura, J.M.G.; Perramon, A.G.; Calle, V.S.; Comadira, P.H. Introducing concepts of circular economy into the public procurement of medicines in Europe. Eur. J. Hosp. Pharm. 2018, 26, 240. [CrossRef]

27. Greer, R.; von Wirth, T.; Loorbach, D. The diffusion of circular services: Transforming the Dutch catering sector. J. Clean. Prod. 2020, 267, 121906. [CrossRef]

28. Milios, L. Advancing to a Circular Economy: Three essential ingredients for a comprehensive policy mix. Sustain. Sci. 2018, 13, 861-878. [CrossRef]

29. Grandia, J.; Voncken, D. Sustainable Public Procurement: The Impact of Ability, Motivation, and Opportunity on the Implementation of Different Types of Sustainable Public Procurement. Sustainability 2019, 11, 5215. [CrossRef]

30. Witjes, S.; Lozano, R. Towards a more Circular Economy: Proposing a framework linking sustainable public procurement and sustainable business models. Resour. Conserv. Recycl. 2016, 112, 37-44. [CrossRef]

31. ConCirMy. Kombinierter Bericht für AP 2.1 und AP 2. ConCirMy: Marktanalyse, Materialbeschreibung und Anforderungsdefinition auf Materialebene (2.1.) Sowie Prozesskettenidentifikation inkl. der Verschiedenen Aktuell Verfügbaren Recyclingtechnologien (2.2.), Internal Project Document; ConCirMy: Berlin, Germany, 2021.

32. $320^{\circ}$. Ein Reifen, der aus Recyclingmaterial Besteht und CO2 Absorbiert. 2021. Available online: https://320grad.de/ein-reifender-aus-recyclingmaterial-besteht-und-co2-absorbiert/ (accessed on 3 September 2021).

33. Walter, C.; PS WELT Materialcheck. Was Taugen Runderneuerte Reifen Wirklich? 2015. Available online: https://www.welt.de/ motor/article138565689/Was-taugen-runderneuerte-Reifen-wirklich.html (accessed on 27 September 2021).

34. OECD. Public Procurement in Germany; OECD: Paris, France, 2019.

35. European Union. Directive 2014/24/EU of the European Parliament and of the Council of 26 February 2014 on Public Procurement and Repealing Directive 2004/18/EC. 2014. Available online: https:/ / eur-lex.europa.eu/legal-content/EN/TXT/HTML/?uri= CELEX:32014L0024\&from=DE (accessed on 1 November 2021).

36. BMU. Umweltfreundliche Beschaffung. 2020. Available online: https://www.bmu.de/themen/nachhaltigkeit-digitalisierung/ konsum-und-produkte/umweltfreundliche-beschaffung (accessed on 1 November 2021).

37. Vergabevorschriften. Die wichtigsten Vergabevorschriften. 2021. Available online: https://www.vergabevorschriften.de/ (accessed on 1 November 2021).

38. BMWI. Bekanntmachung der Verfahrensordnung für die Vergabe Öffentlicher Liefer- und Dienstleistungsaufträge unterhalb der EU-Schwellenwerte (Unterschwellenvergabeordnung-UVgO)_Ausgabe 2017. Available online: http: / / www.verwaltungsvorschriften-im-internet.de/bsvwvbund_02022017_IB6261902.htm (accessed on 2 November 2021).

39. Siedenberg, A. Erfahrungen aus der Praxis Nachhaltiger Beschaffung in Kommunen, Presentation at “Wer Zahlt Bestimmt die Musik", Web-Seminar of the EnergieAgentur.NRW and Prosperkolleg on 25 March 2021. Available online: https:/ / prosperkolleg. de/htevent/wer-zahlt-bestimmt-die-musik/ (accessed on 25 March 2021).

40. BMU. Federal Climate Change Act. 2019. Available online: http://www.gesetze-im-internet.de/englisch_ksg/englisch_ksg.pdf (accessed on 1 November 2021).

41. European Commission. Questions and Answers: A New Circular Economy Action Plan for a Cleaner and More Competitive Europe. 2020. Available online: https:/ / ec.europa.eu/commission/presscorner/detail/en/qanda_20_ (accessed on 1 November 2021).

42. BMU. Green Procurement. 2021. Available online: https://www.umweltbundesamt.de/themen/wirtschaft-konsum/ umweltfreundliche-beschaffung (accessed on 4 November 2021).

43. Besch, A. Vergaberecht und Nachhaltigkeit. 2020. Available online: http://www.nachhaltige-beschaffung.info/DE/ VergaberechtundNachhaltigkeit/neuesvergaberecht_node.html (accessed on 27 September 2021). 
44. Kompass Nachhaltigkeit. Sustainability Compass. 2016. Available online: https://www.kompass-nachhaltigkeit.de/en/ (accessed on 1 November 2021).

45. Sonigo, P.; Bain, J.; Kong, M.A. Policies to Encourage Sustainable Consumption: Full Report; European Communities: Luxembourg, 2012.

46. ConCirMy. Geschäftsmodellspezifikation und Handlungsempfehlungen zur Etablierung eines digitalisierten zirkulären und bio-basierten Systems für die Automobilindustrie Kapitel 1 Regulatorischer Rahmen. Unpublished work. 2019.

47. Strauss, A.L.L.; Corbin, J.M. Basics of Qualitative Research: Grounded Theory Procedures and Techniques, 3. Printing; Sage: Newbury Park, CA, USA, 1991.

48. Legewie, H. Review: Jörg Strübing (2004). Grounded Theory. Zur sozialtheoretischen und epistemologischen Fundierung des Verfahrens der empirisch begründeten Theoriebildung. Forum Qual. Soz. 2006, 7. [CrossRef]

49. Strübing, J. Grounded Theory; VS Verlag für Sozialwissenschaften: Wiesbaden, Germany, 2004.

50. Knuth, A. Gründungsnetzwerke im Wissenschafts-und Hochschulbereich: Herausforderungen für die Wirtschaftsförderung. Zugl.: Potsdam, Univ., Diss., 2008, 1st ed.; Gabler Edition Wissenschaft. Gabler Verlag/GWV Fachverlage GmbH Wiesbaden: Wiesbaden, Germany, 2009.

51. Eisenhardt, K.M. Building Theories from Case Study Research. Acad. Manag. Rev. 1989, 14, 532-550. [CrossRef]

52. Yin, R.K. Case Study Research: Design and Methods, 5th ed.; Sage: Los Angeles, CA, USA, 2014.

53. Witzel, A. The problem-centered interview. FQS Forum: Qualitative Sozialforschung. Forum Qual. Soc. Res. 2000, 1, 22. [CrossRef]

54. FEMNET. Möglichkeiten Einer Ökologisch und Sozial Nachhaltigen Öffentlichen Beschaffung. Leitfaden Erstellt im Auftrag von FEMNET e.V. 2019. Available online: https:/ / femnet.de/download/send/22-beschaffung/98-moeglichkeiten-eineroekologischen-sozial-nachhaltigen-beschaffung-femnet-leitfaden.html (accessed on 27 September 2021).

55. ADAC. Alle ADAC Sommerreifentests. 2021. Available online: https://www.adac.de/rund-ums-fahrzeug/tests/reifen/ sommerreifen/ (accessed on 30 September 2021).

56. Baltrunaite, A.; Giorgiantonio, C.; Mocetti, S.; Orlando, T. Discretion and Supplier Selection in Public Procurement. J. Law Econ. Organ. 2021, 37, 134-166. [CrossRef]

57. Szucs, F. Discretion and Favoritism in Public Procurement. 2020. Available online: https://www.coursehero.com/file/91599488 /Szucs-2020pdf/ (accessed on 14 October 2021).

58. Van Der Waal, E.C.; Das, A.M.; Van Der Schoor, T. Participatory Experimentation with Energy Law: Digging in a 'Regulatory Sandbox' for Local Energy Initiatives in the Netherlands. Energies 2020, 13, 458. [CrossRef]

59. Alaassar, A.; Mention, A.-L.; Aas, T.H. Exploring how social interactions influence regulators and innovators: The case of regulatory sandboxes. Technol. Forecast. Soc. Chang. 2020, 160, 120257. [CrossRef]

60. EPD. Tires. 2021. Available online: https://test1.environdec.com/PCR/Detail/?Pcr=12057 (accessed on 2 November 2021).

61. Lindström, H.; Lundberg, S.; Marklund, P.-O. How Green Public Procurement can drive conversion of farmland: An empirical analysis of an organic food policy. Ecol. Econ. 2020, 172, 106622. [CrossRef] 